\title{
Influence of depth, temperature, and structure of a crustal heat source on the geothermal reservoirs of Tuscany: numerical modelling and sensitivity study
}

\author{
Anozie Ebigbo ${ }^{1,2^{*}} \mathbb{0}$, Jan Niederau ${ }^{1}$, Gabriele Marquart ${ }^{1}$, Ivano Dini ${ }^{3}$, Martin Thorwart ${ }^{4}$, Wolfgang Rabbel ${ }^{4}$, \\ Renate Pechnig ${ }^{5}$, Ruggero Bertani ${ }^{3}$ and Christoph Clauser $^{1}$
}

*Correspondence:

a.ebigbo@imperial.ac.uk

${ }^{1}$ Institute for Applied

Geophysics and Geothermal Energy, E.ON Energy Research Center, RWTH Aachen

University, Mathieustrreet 10, 52074 Aachen, Germany

Full list of author information is available at the end of the article

\section{Abstract}

Granitoid intrusions are the primary heat source of many deep geothermal reservoirs in Tuscany. The depth and shape of these plutons, characterised in this study by a prominent seismic reflector (the K horizon), may vary significantly within the spatial scale of interest. In an exploration field, simulations reveal the mechanisms by which such a heat source influences temperature distribution. A simple analysis quantifies the sensitivity of potentially measurable indicators (i.e. vertical temperature profiles and surface heat flow) to variations in depth, temperature, and shape of the heat source within given ranges of uncertainty.

Keywords: Hydrothermal simulations, Crustal heat source, High-enthalpy reservoir, K horizon, Geothermal energy
\end{abstract}

\section{Background}

Geothermal energy in southern Tuscany has been used for heating and electrical power supply for many decades. Electrical power generation is still increasing, raising the need for new exploration in areas adjacent to the Larderello-Travale and Monte Amiata areas. Such an area (some $10 \mathrm{~km}$ southwest of Monte Amiata; see Fig. 1) with dimensions $23 \times$ $16 \mathrm{~km}$ is the focus of the present study.

Numerical simulations are used to evaluate the geothermal potential of the area, i.e. to predict the expected temperatures and flow rates. Numerical modelling of the Larderello geothermal field has previously been accomplished by Della Vedova et al. (2008) and Romagnoli et al. (2010) to forecast the future evolution and the sustainability of the field. In the same vein, Fulignati et al. (2014) performed hydrothermal simulations of the Monte Amiata area. The present study is similar to these in that it aims at finding a valid numerical representation of the subsurface both with respect to geological structure and physical property distributions, thereby deriving the fluid flow and temperature fields. Moreover, the primary heat source-and hence controlling structure for heat transport-of the geothermal reservoir is studied by quantifying the uncertainties in its temperature, depth, and shape and their influence on the heat transport processes.

(C) 2016 Ebigbo et al. This article is distributed under the terms of the Creative Commons Attribution 4.0 International License (http://creativecommons.org/licenses/by/4.0/), which permits unrestricted use, distribution, and reproduction in any medium provided you give appropriate credit to the original author(s) and the source, provide a link to the Creative Commons license, and indicate if changes were made. 


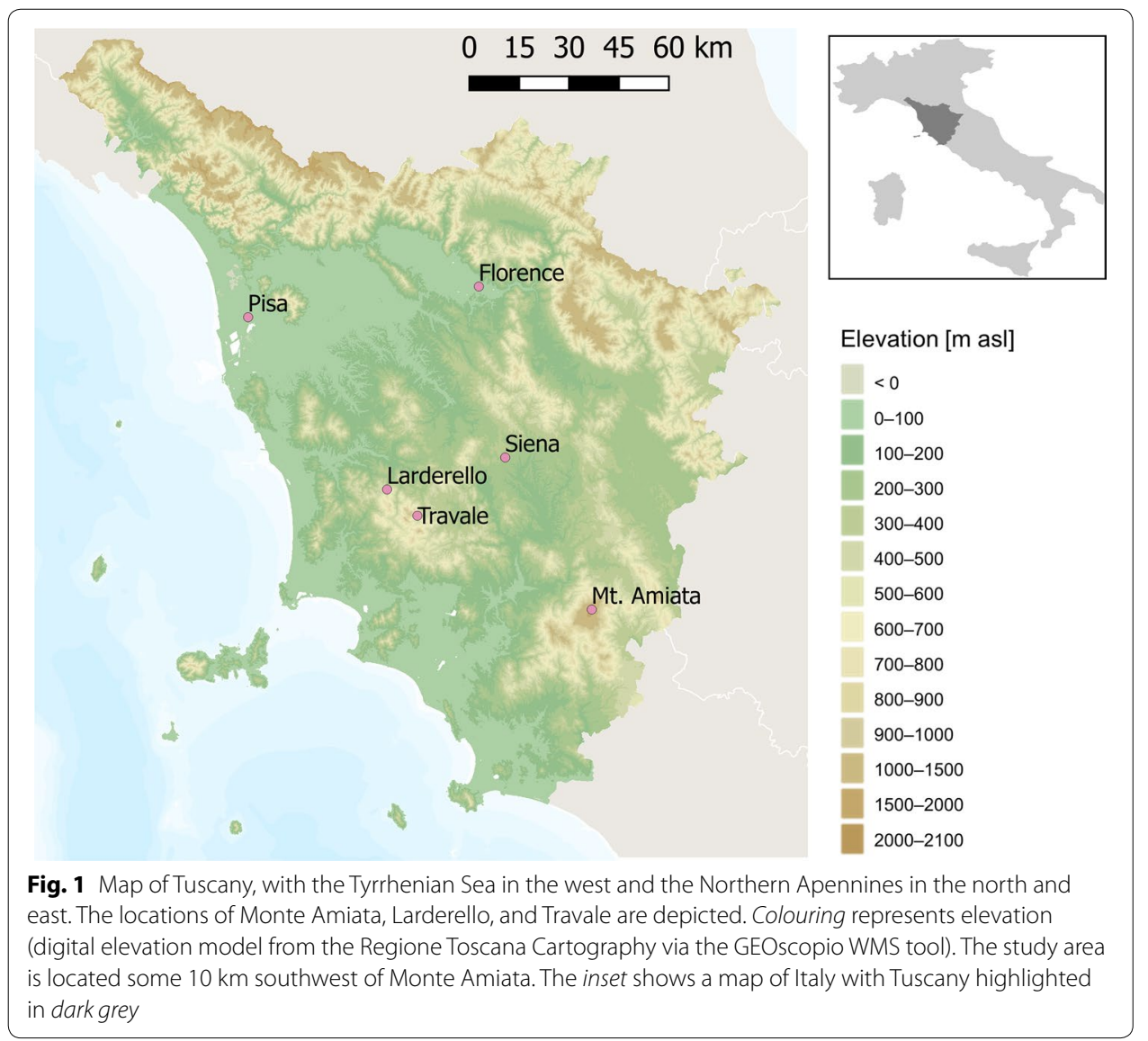

\section{Crustal heat source}

Young (Pliocene to Quaternary) granite plutons have been identified as the primary heat source in the southern Tuscan geothermal areas including Larderello-Travale and Monte Amiata (Brogi 2008b; Frondini et al. 2009; Gianelli et al. 1997, 1988). These acidic intrusive bodies belong to the Tuscan Magmatic Province (Innocenti et al. 1992) and can be linked to the extensional tectonic setting in the region (Brogi 2008b). They appeared as from the Middle Miocene in Corsica to the Late Pleistocene in the Tuscan region (e.g. Dini et al. 2005; Peccerillo 1999). They are non-uniformly distributed and emplaced at various depths, leading to rather large differences in surface heat flow (100-1000 mW/ $\mathrm{m}^{2}$; Bellani et al. 2004) in this inner Northern Apennine area.

A correlation between the depth of this heat source and a high-amplitude seismic reflector (called K horizon) has been described, among others, by Bellani et al. (2004), Cameli et al. (1993, 1998), Gianelli et al. (1997), Liotta and Ranalli (1999), and Vanorio et al. (2004). As stated by Liotta and Ranalli (1999), "this horizon ranges in depth between 3 and $12 \mathrm{~km}$, and can be followed almost continuously from the Tyrrhenian coast to the central part of the Apennines'". The shallowest areas are in the Larderello-Travale and Monte Amiata geothermal areas (Cameli et al. 1993; Gianelli et al. 1997).

The nature of the K horizon is still unknown, and since its first detection, several geological interpretations have been proposed: 
1. a kinematically active rheological boundary which separates a brittle upper part from a ductile lower part (Cameli et al. 1993);

2. a kinematic shear belt with entrapped fluids in fractured levels (Liotta and Ranalli 1999) located at the top of the brittle/ductile transition (Bellani et al. 2004, 2005); and

3. a contact aureole associated with mineralised breccias and tractites related to a thermometamorphic process in the contact zone between young (Quaternary) intrusions of granite and calcium-bearing silicate rocks (Bertini et al. 2005).

The third explanation was stimulated by observations of a contact aureole on the oldest eroded plutons on Elba Island (Dini et al. 2002; Rossetti et al. 2007). Following this interpretation, the $\mathrm{K}$ horizon was created by the intrusion and has the same age and (roughly) the same depth as the intrusion.

The first and second interpretations both assume that there is a shear zone at the $\mathrm{K}$ horizon. The second one, however, explains the high seismic reflectivity at the K horizon with the presence of entrapped (highly pressured, supercritical) fluids. Bellani et al. (2005) studied the intersections of extensional shear zones and the K horizon in the Larderello area and found that the $\mathrm{K}$ horizon loses its reflectivity at such intersections. They attributed this finding to fluid migration from the $\mathrm{K}$ horizon towards the surface along the brittle shear zones. The consequence of this interpretation would be a non-negligible permeability along parts of the $\mathrm{K}$ horizon. Interpreting the $\mathrm{K}$ horizon as a shear zone also implies that it is not directly related to an intrusion (i.e. a heat source) and was presumably formed by repeated tectonic events over a long period of time. This would imply that since the $\mathrm{K}$ horizon is not causatively related to the intrusion, the depth of the heat source is uncertain to some degree.

Although the manner of creation of the $\mathrm{K}$ horizon is uncertain, it can be correlated with a certain temperature. In a comprehensive study, Liotta and Ranalli (1999) attribute a relatively narrow temperature range to the $\mathrm{K}$ horizon and conclude that the $\mathrm{K}$ horizon "follows approximately the $450 \pm 50^{\circ} \mathrm{C}$ isotherm and is compatible with the expected depth of the brittle/ductile transition for high pore fluid pressures and a wide range of strain rate".

\section{Geological model}

The geological reservoir model is constructed assuming a conceptual model based on work by Batini et al. (2003), Brogi (2006, 2008a, b, c), and references therein. The investigated area is situated in the inner zone of the orogenic belt of the Northern Apennines. It was affected by at least two distinct tectonic phases-compression followed by extension. Compression gave rise to an eastward stacking of various lithological units, ranging from marine and continental sediments to metamorphites. The following units are included explicitly in the geological model (cf. Fig. 2):

(a) Pliocene (including Quaternary and Neogene) sediments, accumulated in young graben systems and unconformably overlying pre-Neogene units;

(b) Ligurian and Subligurian units, which consist of remnants of the oceanic crust and its marine to pelagic sedimentary cover; 


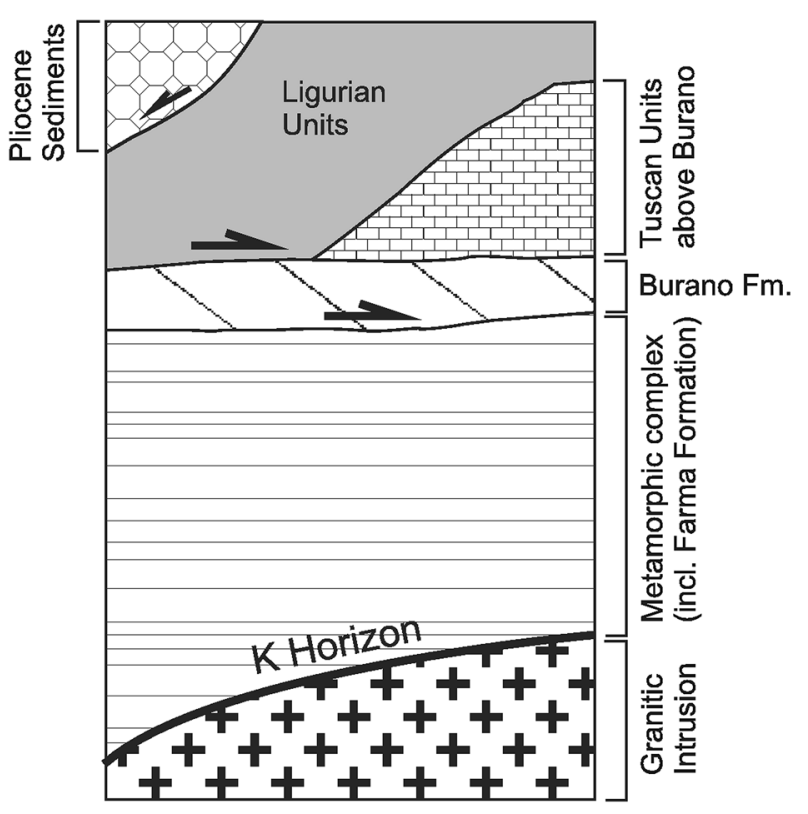

Fig. 2 Simplified stratigraphic pile of the Monte Amiata area. Subdivisions of the Tuscan units and the metamorphic complex are omitted, as they are not considered in the model. Note that the K horizon does not represent a lithological boundary

Tuscan Nappe units, which are represented by continental margin deposits (Triassic to Miocene) of the Adria paleomargin, comprising:

(c) Carbonate and pelagic-turbidite successions ("TUaB-Tuscan units above Burano");

(d) The Burano formation, which forms the basal unit of the Tuscan Nappe successions and consists mainly of anhydrite and carbonates;

(e) The deeper Tuscan metamorphic complex, referred to as the Farma formation. Below the metamorphic complex, the prominent seismic reflector, the $\mathrm{K}$ horizon, marks the bottom of the model domain.

(f) In the context of this study, the $K$ horizon is treated as an isothermal boundary at the bottom of the model, and the rocks below are attributed to a granitic intrusion.

The compressional stress regime in Tuscany changed to an extensional stress regime during the Miocene (Brogi 2006), as is indicated by two generations of normal faults (low- and high-angle normal faults) throughout the inner zone of the Northern Apennines. The study area lies in this inner zone and, hence, was affected by these tectonic phases, i.e. compression followed by extension. Integrated studies in the inner zone of the Northern Apennines have suggested that, during the extensional phase, the Tuscan Nappe units formed mega-boudins (e.g. Brogi , 2006, 2008a), "isolated" patches of Tuscan Nappe successions separated from other strata by low-angle normal faults. 
High-angle normal and transtensional faults reflect the youngest stage of extension, displacing previously developed structures (Brogi 2008b).

While this hypothesis explains geologic field data, it primarily considers the sedimentary complex above a detachment horizon. The Burano formation reflects the incompetent basal evaporitic layer of the Tuscan Nappe units and served as a detachment layer during the tectonic evolution of the inner zone of the Northern Apennines. Thus, it separates the upper sedimentary complex from the deeper Tuscan metamorphic complex. The metamorphic complex consists of the Monticiano-Roccastrada Unit (MRU) which is usually divided into three sub-units (MRU1-3). From top to bottom, these are The Verrucano unit (MRU3, Triassic), comprising metasandstones and metaconglomerates; a phyllite succession (MRU2, Carboniferous), which consists of graphitic phyllites and metasandstones; and a micaschist group (MRU1). The MRU1 as well as a deeper gneiss complex known from other geothermal areas in Tuscany is not encountered in boreholes close to the study area, but found as xenoliths in Quaternary lavas in the area (van Bergen 1983). In the context of this study, the Palaeozoic phyllites of the MRU1 and MRU2 are referred to as the Farma formation.

The structural model of the subsurface is constructed by picking reflective seismic horizons along five seismic profiles and three-dimensional interpolation (Thorwart et al. 2015) using an implicit modelling approach implemented in the software 3D GeoModeller (Lajaunie et al. 1997). High-angle normal faults, inferred from seismic sections and surface geology, are included as structural elements which displace older strata. The assignment of lithological units $(a-e)$ follows the described geological framework and information from surface geology (see Fig. 3). Units $a-c$ are considered to be cover units due to their low permeabilities. The Burano unit $(d)$ is the primary (and shallow) geothermal reservoir. Although the Farma unit $(e)$ is part of the metamorphic basement and has a low permeability, Bertini et al. (1995) and Barelli et al. (2010) point out the existence, in nearby areas, of a deep geothermal reservoir within this formation (see the "Petrophysical properties" section for further details). This is referred to in Fig. 3 as the (presumed) deep reservoir.

Surface topography was included based on a digital terrain model (provided by Enel Green Power) with a resolution of $20 \times 20 \mathrm{~m}$.

\section{K horizon}

The position of the K horizon (see Fig. 4), which defines the depth of the heat source, can only be resolved within rather large confidence bounds. The main reasons for the uncertainties are outlined in the following. While some of these issues also pertain to the various rock units of the model, the focus here is on the heat source which is the single most important constraint of the geothermal reservoir and is a feature common to other Tuscan geothermal reservoirs.

Some of the major lithological units, and the K horizon, can be identified by interpretation of the reflection seismic profiles. However, the strength of the refection signal varies considerably along the profiles with local ambiguities and offsets (Riedel et al. 2015). Similar phenomena have been observed in other seismic profiles which resolve the K horizon where "multiple reflections and complex appearance due to interconnecting reflections, refractions, and diffraction" have been reported (Gianelli et al. 1997). 


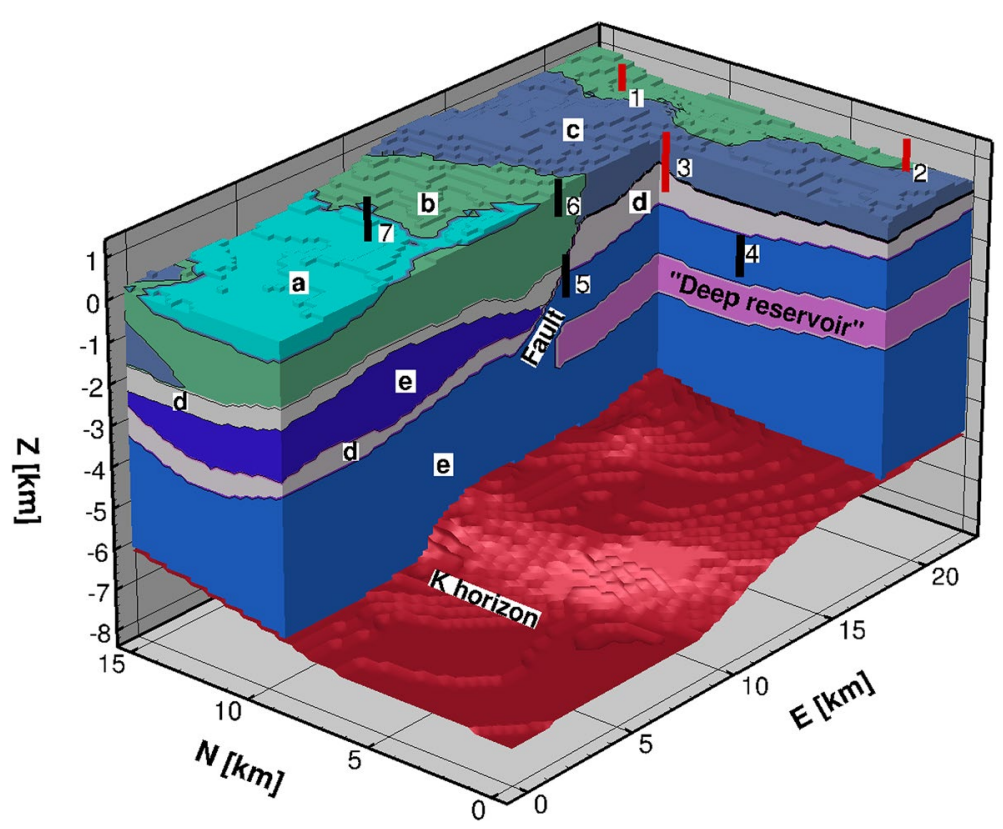

Fig. 3 Geological model (with surface topography). The structural model is based on depth migration of refection seismic data, horizon picking, manually included fault planes, and numerical interpolation. Geological units are assigned following a general geological framework explained in the text: $a$ Pliocene, $b$ Ligurian units, c Tuscan units above Burano (TUaB), $d$ Burano, and $e$ Farma. Ligurian units fill accumulation spaces between separated patches of the Tuscan Nappe unit. The Monticiano-Roccastrada Unit (MRU) has not been divided into its subgroups and is referred to as the Farma formation. The so-called deep reservoir, which is part of the Farma unit, is characterised by a high fracture density and, hence, permeability. It is assumed that it does not extend to the west of the main fault where a stacking of the MRU and the Burano formation has been inferred from seismic analysis (Thorwart et al. 2015). Red lines show the locations of Boreholes 1-3, while Locations 4-7 (black lines) represent the shallow wells for which surface heat flow measurements are available

Further, since only five crisscrossing seismic profiles are available, additional uncertainty arises regarding the shape of the $\mathrm{K}$ horizon through interpolation between the profiles and extrapolation towards the borders of the study area.

Even if one had excellent reflectors, the assignment of the depth positions of the lithological layers would only be possible with correct information on their seismic velocities (Thorwart et al. 2015). A seismic depth migration analysis of the time-recorded reflection signals leads to uncertainty in position that increases with depth. The $\mathrm{K}$ horizon in the study area is deeper than $5 \mathrm{~km}$, and the uncertainty in determining its depth given the available information has been estimated to be approximately $300 \mathrm{~m}$ (Riedel et al. 2015).

\section{Mathematical model}

\section{Balance equations}

The conservation of mass of water in a porous/fractured medium is accounted for in steady state with the equation:

$$
\nabla \cdot(\varrho \mathbf{v})=0 .
$$




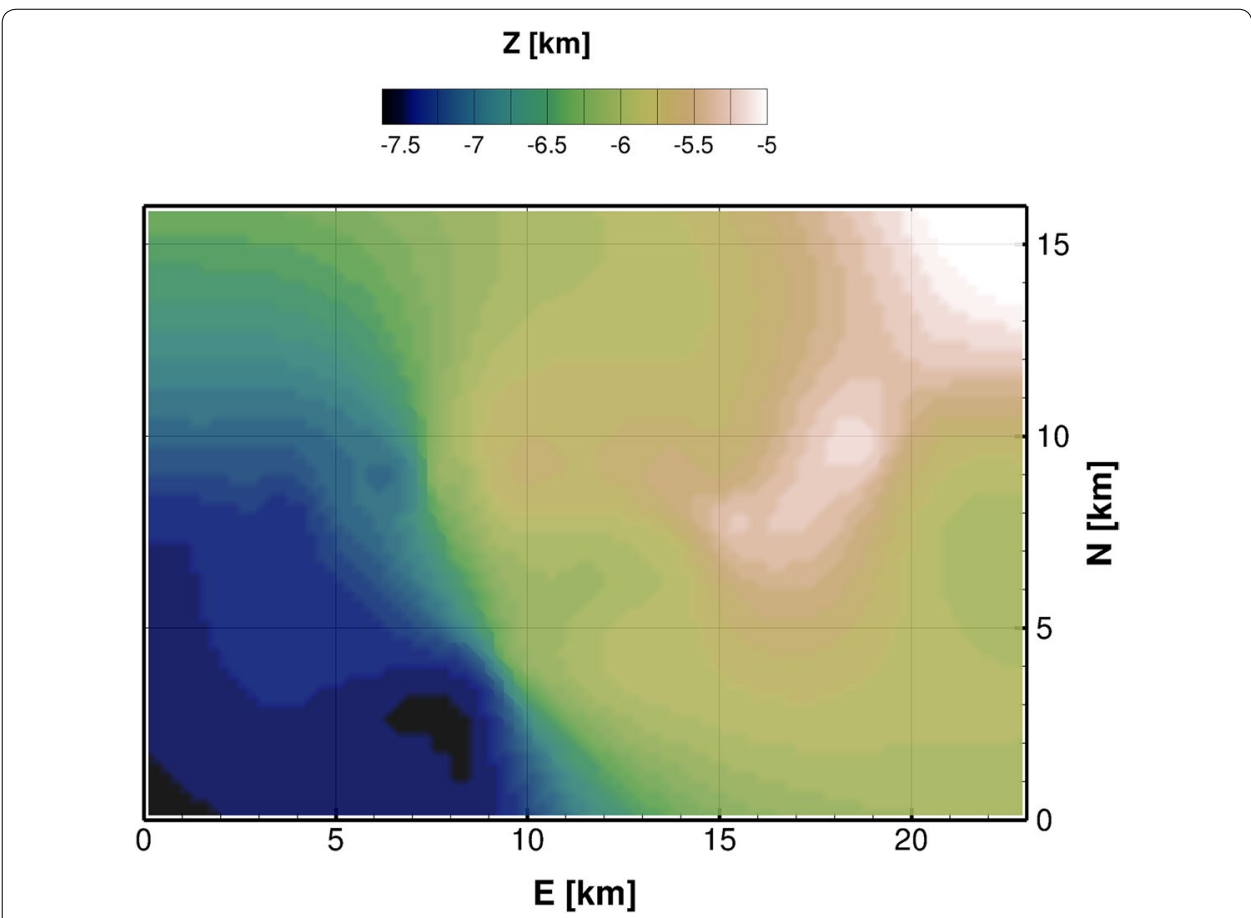

Fig. 4 Depth of the K horizon as obtained from reflection seismic signal picking along five depth-migrated, two-dimensional seismic profiles and lateral inter- and extrapolation

Here, $\varrho\left[\mathrm{kg} / \mathrm{m}^{3}\right]$ is the density of water and $\mathbf{v}[\mathrm{m} / \mathrm{s}]$ is the Darcy flux which is calculated with the Darcy equation:

$$
\mathbf{v}=-\frac{k}{\mu} \nabla(p+\varrho g z)
$$

The intrinsic permeability $k\left[\mathrm{~m}^{2}\right]$ is assumed to be isotropic. $\mu[\mathrm{Pa} \mathrm{s}], p[\mathrm{~Pa}], g\left[\mathrm{~m} / \mathrm{s}^{2}\right]$, and $z[\mathrm{~m}]$ are viscosity of water, pressure, gravity acceleration, and the vertical coordinate (positive upwards), respectively.

Advection, conduction, and radiogenic heat production are accounted for in the energy balance equation, here, in steady state:

$$
\nabla \cdot\left(\varrho h \mathbf{v}-\lambda_{\mathrm{e}} \nabla T\right)=H .
$$

The specific enthalpy of water is represented with $h[\mathrm{~J} / \mathrm{kg}]$, while $H\left[\mathrm{~W} / \mathrm{m}^{3}\right]$ is the rate of radiogenic heat production. The effective thermal conductivity, $\lambda_{\mathrm{e}}[\mathrm{W} /(\mathrm{m} \mathrm{K})]$, is calculated as the weighted geometric mean of the thermal conductivities of water, $\lambda_{\mathrm{w}}$, and the rock matrix, $\lambda_{m}$ (e.g. Clauser 2011):

$$
\lambda_{\mathrm{e}}=\lambda_{\mathrm{w}}^{\phi} \lambda_{\mathrm{m}}^{(1-\phi)},
$$

where $\phi$ is the porosity.

\section{Constitutive relations}

Non-linearities in the balance equations stem primarily from the pressure and temperature dependence of the physical properties of water (i.e. density, viscosity, specific 
enthalpy, and thermal conductivity). In the deep part of the reservoir, supercritical conditions for water are reached. The physical properties of water in sub- and supercritical conditions are calculated using the correlations provided by the International Association for the Properties of Water and Steam (Wagner et al. 2000). It should be noted that the physical conditions that currently prevail in the reservoir do not allow for the existence of two-phase (water/steam) conditions. This is illustrated in Fig. 5 which shows results of the simulations presented in the "Hydrothermal simulations" section. The pressure and temperature conditions at each grid point have been plotted in the figure. There is a continuous transition from liquid to supercritical water with depth. The absence of water vapour is also supported by observations in deep boreholes in the area. As such, a description of the state of the reservoir with a single fluid phase, as is done here, is sufficient.

The thermal conductivity of the rock matrix decreases with temperature. This is included in the model in the same manner as Pasquale et al. (2014), in which the correlation by Sekiguchi (1984) is applied to northern Italian rocks:

$$
\lambda_{\mathrm{m}}=1.8418+\left(\lambda_{\mathrm{m}, 0}-1.8418\right)\left(\frac{1}{0.002732 T+0.7463}-0.2485\right) .
$$

Here, $\lambda_{\mathrm{m}, 0}$ is the matrix conductivity at $20^{\circ} \mathrm{C}$.

The permeabilities of the rock masses are primarily caused by fractures, which commonly results in a depth-dependent permeability (e.g. Manning and Ingebritsen 1999), the dependence on depth being caused by fracture sealing due to the overburden pressure. Hence, using the correlation by Wei et al. (1995), which is supposed to be independent of rock type, permeability is expressed as a function of overburden thickness $z_{\mathrm{b}}$ and permeability at the ground surface $k_{0}$ :

$$
k=k_{0}\left(1-\frac{z_{\mathrm{b}}}{58+1.02 z_{\mathrm{b}}}\right) \cdot 3
$$

Wei et al. (1995) base their correlation on a large database (Snow 1968) of injection tests comprising eight rock types. The correlation is very similar to, but simpler, than that of

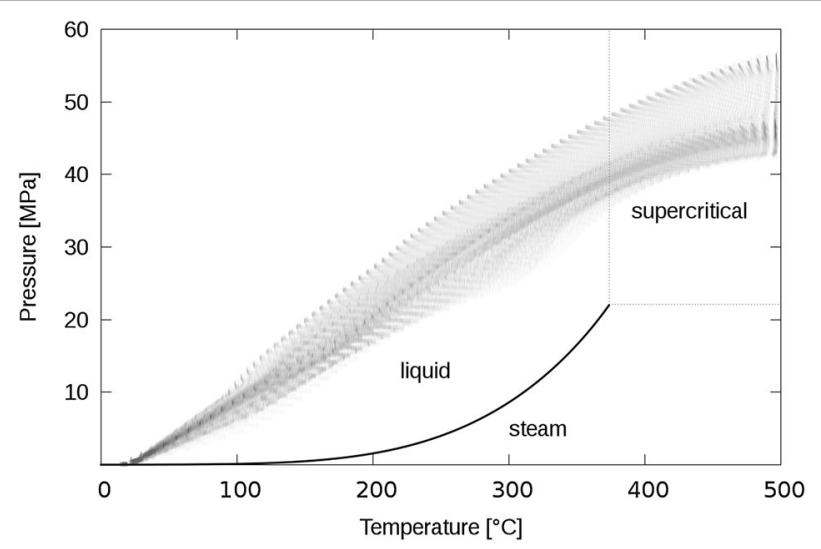

Fig. 5 Conditions in the reservoir plotted on the phase diagram of water. These are results of the simulations presented in the "Hydrothermal simulations" section. Each grid node is represented with a light grey symbol 
Jiang et al. (2010), which allows one to vary the residual aperture (the fracture aperture at very high stress). Unfortunately, this information is not available here, and the correlation by Wei et al. (1995) is deemed sufficient. For a comparison of the two approaches, see Jiang et al. (2010).

\section{Temperature data}

Temperature measurements are available in three boreholes (Boreholes 1-3 in Fig. 3) located in the eastern part of the study area. All temperature measurements were carried out with a mechanical or electronic Kuster-or equivalent-device.

In Borehole 1, temperatures were measured in static conditions via temperature/pressure logging (Kuster device), i.e. several years after borehole completion. There were also six measurements at bottom hole conducted during breaks in drilling (lasting about $24 \mathrm{~h}$ ) whenever possible and useful and, mostly, without losses of circulation fluid (i.e. without ongoing thermal disturbances). These temperatures were extrapolated, analysing about $24 \mathrm{~h}$ of transient temperature data using the BarPal method (Barelli and Palamà 1981). Other extrapolation methods [i.e. Horner plot (Horner 1951) and Horner-Roux (Roux et al. 1979)] were applied, but with less reliable results. The extrapolated values fit well with the values recorded with the temperature/pressure log in static conditions.

For Boreholes 2 and 3, in situ temperature measurements were conducted at 336 and 168 h, respectively, after drilling was completed (in 1968 and 1964, respectively). Measurements carried out after intermediate times demonstrate that the final values can be considered stable. Finally, the precision of static temperature data is estimated to be less than $\pm 2{ }^{\circ} \mathrm{C}$ for Borehole 1 and less than $\pm 5^{\circ} \mathrm{C}$ for Boreholes 2 and 3 .

In four shallow wells (Locations 4-7 in Fig. 3), heat flow was determined using either two or four thermocouples installed $10 \mathrm{~m}$ apart at the bottom of each borehole. Temperature measurements were conducted periodically over several months, until reaching static conditions. Measurement of the thermal conductivity on cores drilled from the same interval as the temperature measurements allowed the calculation of heat flow. For Boreholes 1-3, heat flow was calculated using the shallowest available pair of temperature measurements and estimated values of thermal conductivity.

\section{Petrophysical properties}

The petrophysical properties (porosity, matrix thermal conductivity, and heat production rate) of the reservoir units Burano and Farma have been obtained from borehole log analyses and laboratory measurements on cores and cuttings. These data (borehole logs, cores, and cuttings) were available from three boreholes in the study area. A total of 78 cutting samples were taken from two boreholes (sampling distance 50-100 m) and investigated in the laboratory for grain density and thermal conductivity of the rock matrix. Thermal conductivity measurements on cuttings were performed by a line source equipment following the procedures of Erbas (2001). In addition, ten core samples were investigated for thermal conductivity by an optical core scanner (Popov et al. 1999). The core samples also underwent standard investigation for porosity and bulk and grain density.

The objective of log analysis is to provide a detailed characterisation of the reservoir formations with respect to their thermal properties such as the thermal conductivity and radiogenic heat production. Borehole geophysical data are used to derive continuous 
logs of volumetric rock composition and porosity, serving as input data for the prediction of thermal conductivity. These investigations concentrate on the two reservoir units of the Burano and the Farma formation. Formation evaluation procedures for prediction of rock composition and porosity are based on different methods already in use for oil and gas wells (e.g. Ellis and Singer 2007; Schlumberger 1998; Serra 1984). These methods have been adapted to the geological reservoir conditions of this study.

The gamma ray is used to differentiate between quartz/feldspar and mica/biotite/chlorite within the Farma phyllites, adapting the standard approach of sand/clay differentiation in siliciclastic sediments. Volumetric rock composition and petrophysical data from laboratory investigation allow one to correct for variations in matrix density and matrix slowness, a parameter used by methods for porosity prediction from density and sonic logs (Wyllie equation). A more sophisticated approach is applied for the Burano formation, solving multi-log/multi-component equations for the components of dolomite, anhydrite, calcite, accessorial ore minerals, and water (Doveton 1994).

Once the volumetric amounts of the rock components and the porosity have been determined, continuous profiles of thermal conductivity can be generated. Here, we use the geometric mixing law which has been proven to be a good theoretical description of the effective thermal conductivity of a rock/water mixture (Hartmann et al. 2005, 2008). The thermal conductivity profiles derived from the logs are calibrated with the laboratory measurements (Fig. 6). Using these profiles, statistical values of effective thermal conductivity are calculated for the stratigraphic units of the 3D model.

For the cover units $(a-c)$, almost no log data are available. Porosity and thermal conductivity have been assumed as shown in Table 1 . These are in agreement with literature values from the Larderello area (Bellani et al. 2004; Romagnoli et al. 2010).

Radiogenic heat production rates for the Burano, Farma, and Ligurian units as well as the TUaB are calculated from gamma-ray logs as given by Bücker and Rybach 1996). The $\log$ profiles of porosity, thermal conductivity, and radiogenic heat production are used to calculate mean values and standard deviations. These model input parameters are summarised in Table 1.

\section{Permeability}

Apart from some very shallow aquifers (not explicitly resolved in the model), the lithological units addressed here are composed of almost impermeable rocks. The Ligurian unit comprises low-permeability shaly flysch and sandstones. Similarly, clayey-marly lithotypes constitute the TUaB. These units act as a cap rock for the shallow geothermal reservoir hosted in the Burano formation (Barelli et al. 2010; Fulignati et al. 2014; Romagnoli et al. 2010). The primary permeability of the evaporites of the Burano formation is also very low. However, as has been observed in the geothermal aquifers in Larderello (e.g. Romagnoli et al. 2010) and Monte Amiata (e.g. Fulignati et al. 2014), a secondary, fracture-induced permeability exists. This can be related to an extended subhorizontal shearing of the Burano formation during the compressional stage followed by steep fractures during the extensional phase. In addition, the Burano formation has been described as vuggy, at least locally, due to calcite dissolution (Fulignati et al. 2014; Lugli 2001), which may contribute to its high permeability. 


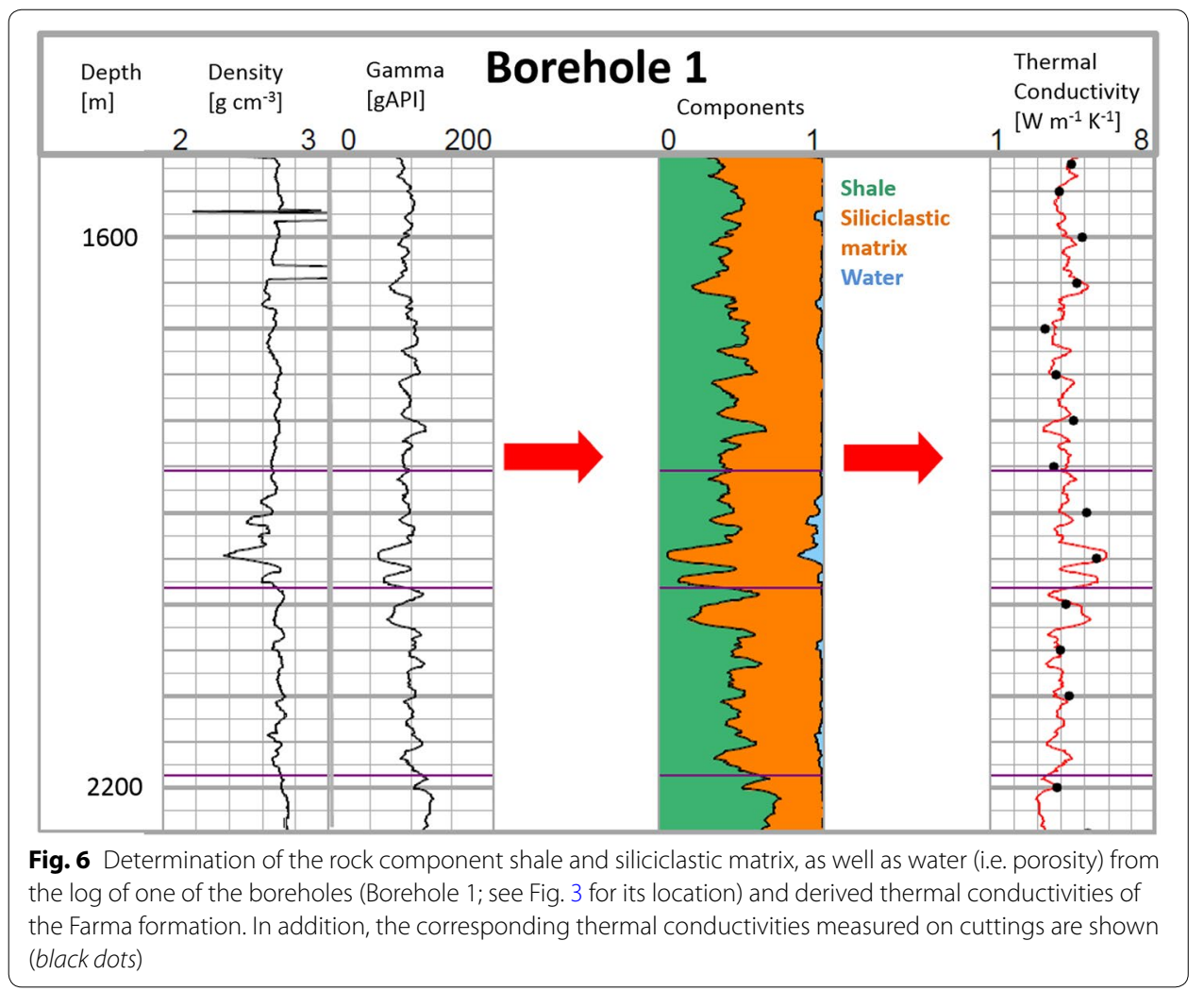

Table 1 Petrophysical properties-including porosity $\phi$, matrix thermal conductivity $\lambda_{\mathrm{m}}$ heat production rate $H$, and matrix density $\varrho_{m}$ - of the various rock units

\begin{tabular}{lllll}
\hline Unit & $\begin{array}{l}\boldsymbol{\phi} \\
{[-]}\end{array}$ & $\begin{array}{l}\lambda_{\mathbf{m}} \\
{[\mathbf{W} /(\mathbf{m ~ K})]}\end{array}$ & $\begin{array}{l}\boldsymbol{H} \\
{\left[\boldsymbol{\mu W} / \mathbf{m}^{\mathbf{3}}\right]}\end{array}$ & $\begin{array}{l}\boldsymbol{\varrho}_{\mathbf{m}} \\
{\left[\mathbf{g} / \mathbf{c m}^{\mathbf{3}}\right]}\end{array}$ \\
\hline (a) Pliocene & 0.05 & 1.9 & 0.23 & - \\
(b) Ligurian & 0.05 & 2.2 & $0.23(7)^{\mathrm{b}}$ & - \\
(c) TUaB & 0.05 & 2.7 & $0.37(16)^{\mathrm{b}}$ & - \\
(d) Burano & $0.02(3)^{\mathrm{b}}$ & $4.7(3)^{\mathrm{b}}$ & $0.16(12)^{\mathrm{b}}$ & $2.94(4)^{\mathrm{a}}$ \\
(e) Farma & $0.03(5)^{\mathrm{b}}$ & $4.1(12)^{\mathrm{b}}$ & $1.43(39)^{\mathrm{b}}$ & $2.78(10)^{\mathrm{a}, \mathrm{b}}$ \\
\hline
\end{tabular}

The values are obtained from ${ }^{a}$ borehole cores, ${ }^{b}$ cuttings, and/or clogs as outlined in the text. Values in italics indicate estimated values. Standard deviations are given in parenthesis. $\lambda_{m}$ is given for surface conditions

The temperature-depth profile in one of the boreholes in the study area, i.e. Fig. 7i, shows a distinct zone with a very low temperature gradient (approximately $0.012 \mathrm{~K} / \mathrm{m}$ ) within the metamorphic basement (similar profiles have also been reported by Barelli et al. (2010), Ceroti et al. (2015), and Fulignati et al. (2014)). This is in contrast to a temperature gradient value of about $0.11 \mathrm{~K} / \mathrm{m}$ in the shallower parts of the Farma unit. This decrease in vertical temperature gradient could be due to a higher thermal conductivity in that zone or due to convection as a result of higher permeability. Given the thermal conductivity of the Farma unit at this depth of $2.8 \mathrm{~W} /(\mathrm{m} \mathrm{K})$, the upward heat flux at the location of Borehole 1 is $313 \mathrm{~mW} / \mathrm{m}^{2}$. If a higher thermal conductivity were indeed the cause of the reduction in temperature gradient, it would imply a thermal conductivity of 


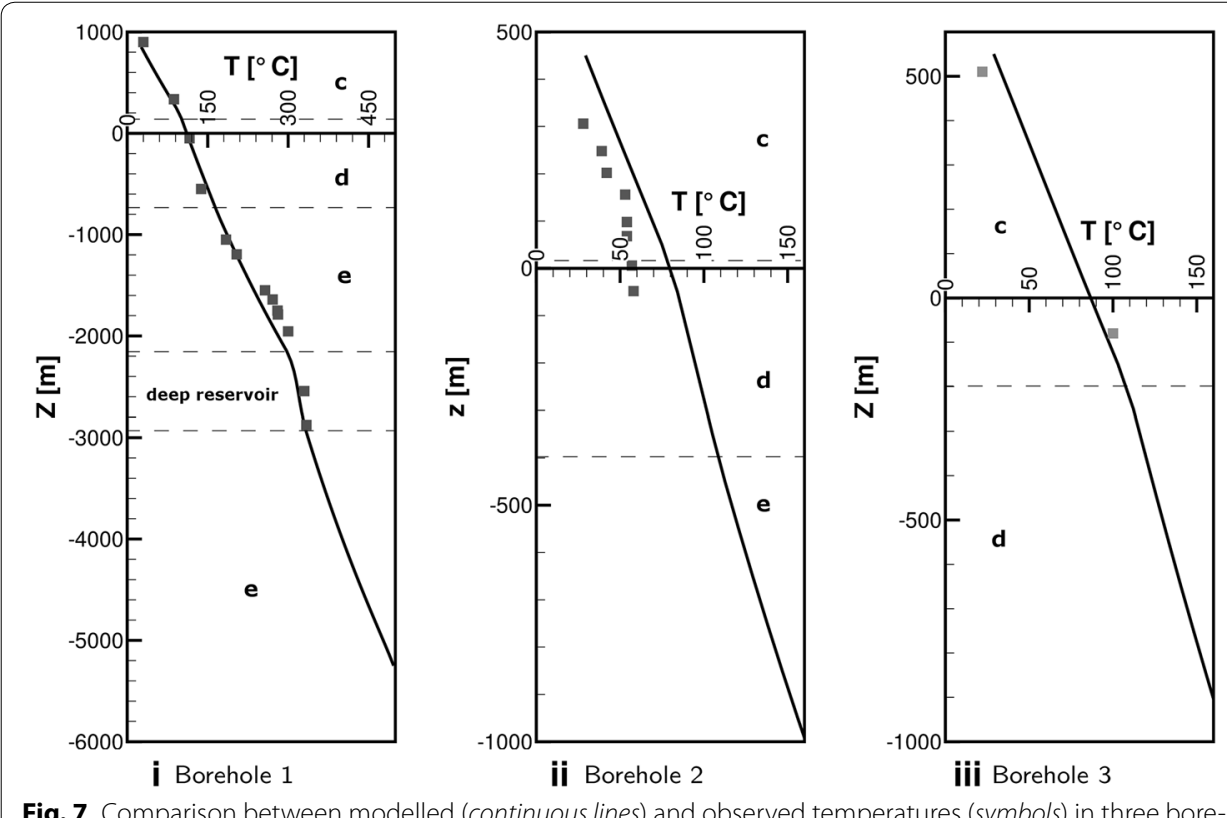

holes (i-iii) in the study area. Dashed lines indicate the boundaries between various strata of the numerical model, i.e. TUaB (c), Burano unit (d), Farma unit (e), and the deep reservoir. Borehole locations are shown in Figs. 3 and 9 .

$\frac{0.313 \mathrm{~W} / \mathrm{m}^{2}}{0.012 \mathrm{~K} / \mathrm{m}}=26 \mathrm{~W} /(\mathrm{mK})$ which is unrealistically high. Instead, it appears more reasonable that there is a deep geothermal reservoir (i.e. a zone of high permeability) within the Farma unit within which convective heat transport reduces vertical temperature gradients. However, it should be noted that the existence of this deep geothermal reservoir is not supported by the reflection seismic data. It is assumed here that it is a zone of interconnected fractures that does not produce a coherent seismic signal.

The minimum thickness of this deep reservoir can be estimated roughly from the temperature profiles and its permeability from the sudden decrease in the temperature gradient due to hydrothermal convection in the permeable layer (see Fig. 7i). As shown in Fig. 3, it has been assumed that the deep reservoir is only present in the eastern part of the model area and ends at the fault. However, there is no evidence to prove its existence or non-existence west of the fault.

For the hydrothermal simulations presented in the "Hydrothermal simulations" section, the permeabilities of the permeable reservoir rock units have been varied within plausible ranges to find the best fit to the available borehole temperature observations. All permeabilities are shown in Table 2. The variations in permeability of the reservoir rocks are due to fracture closure with depth [see Eq. (6)]. Laboratory measurements show that the permeability of flysch and sandstones is highly variable and depends on porosity, clay content, micro-fractures, and cementation (observed values range between $10^{-12}$ and $10^{-19} \mathrm{~m}^{2}$ (e.g. Hajto 2015; Pape et al. 2000)). The Ligurian units in Tuscany show low permeabilities and are known to act as aquicludes (e.g. Baiocchi et al. 2006). The Ligurian unit is the most important cover of the Burano unit in our study area. The thin Pliocene sediments and the carbonates and pelagic sediments of the Tuscan unit above the Burano are also known to have permeabilities that are at least 50-100 times 
Table 2 Fitted permeabilities for the hydrothermal simulations (left) and comparison to values from other modelling studies (right): Fulignati et al. (2014) [1] and Romagnoli et al. (2010) [2]

\begin{tabular}{llll}
\hline Unit & $-\log \left(\boldsymbol{k}\left[\mathbf{m}^{2}\right]\right)$ & & \multicolumn{2}{l}{ Other modelling studies } \\
\cline { 4 - 4 } & & {$[\mathbf{1}]$} & \\
\hline (a) Pliocene & 18 & 17 & $\geq 20$ \\
(b) Ligurian & 18 & 17 & $\geq 20$ \\
(c) TUaB & 18 & 13 & $13-16$ \\
(d) Burano & $14.0-15.4$ & 16.3 & \\
(e) Farma & $17.0-18.0$ & 13.3 & \\
Deep reservoir within Farma & $13.7-14.0$ & & \\
\hline
\end{tabular}

The given ranges are due to the dependence of permeability on depth. Values in italics indicate estimated values (not fitted)

less than those of the reservoir rocks (Della Vedova et al. 2008). Therefore, a permeability of $10^{-18} \mathrm{~m}^{2}$ has been assigned to all three cover units, which is about 100 times less than the lowest permeability value of the Burano unit. This cover unit permeability was not varied. Table 2 also shows permeability values used in other modelling studies from both the Larderello-Travale and Monte Amiata areas. A comparison shows that the values obtained from the fitting are within reasonable ranges.

\section{Numerical model}

The equations from the "Balance equations" section are discretised in space with a finitedifference scheme. This is implemented in the code SHEMAT-Suite, a simulator capable of modelling steady-state and transient hydro-geothermal reservoirs (Rath et al. 2006; Clauser 2003).

\section{Model discretisation}

The structural model shown in Fig. 3, of dimensions $23 \times 16 \times 9 \mathrm{~km}$ in $E$ (East), $N$ (North), and $Z$ (depth) directions, respectively, has been discretised with a hexahedral grid with block dimensions of $250 \times 250 \times 100 \mathrm{~m}$, which yields a total of about half a million grid nodes.

\section{Boundary conditions}

At the top of the domain, i.e. at the ground surface, the temperature depends on air temperature and, thus, topography. The average air temperature gradient is estimated as $1 \mathrm{~K}$ for $184 \mathrm{~m}$ of altitude (Claps et al. 2008). Assuming that the land surface temperature has the same gradient, shallow- well temperature measurements (ranging between 22 and $41{ }^{\circ} \mathrm{C}$ at depths between 147 and $200 \mathrm{~m}$ below the ground surface) are used to determine the absolute values of the temperature distribution at the top of the domain. Pressure at the ground surface is atmospheric $(101325 \mathrm{~Pa})$. The implicit assumption here is that the groundwater table and the ground surface coincide.

The $\mathrm{K}$ horizon is assumed to represent an isotherm, thus providing a boundary condition at the bottom of the domain. The temperature of the $\mathrm{K}$ horizon in the model is varied within the range mentioned in the "Background" section and in accordance with Liotta and Ranalli (1999), i.e. $450 \pm 50^{\circ} \mathrm{C}$. However, the maximum value, $500^{\circ} \mathrm{C}$, matched the borehole temperature measurements in the model best. Assuming that 
the granitic intrusion below the $\mathrm{K}$ horizon is impermeable, there is no flow across this boundary.

The validity of these assumptions (and bottom boundary conditions) depends on the nature of the $\mathrm{K}$ horizon and the heat source. The temperature at the $\mathrm{K}$ horizon and its uncertainty estimate are supported by many temperature observations in boreholes. However, it is not obvious whether 1) the heat source has been in place long enough to establish a steady thermal field in the entire model domain; 2) the temperature of the heat source is changing sufficiently slowly to justify the use of a steady-state boundary condition.

The plutonic complex which constitutes the intrusion (i.e. heat source) has been assumed to have built up incrementally 3.8 to $1.3 \mathrm{Ma}$ ago (Dini et al. 2005; Spinelli et al. 2015). Using 1.3 Ma as the time of the last thermal pulse, a characteristic vertical length scale for thermal diffusion can be estimated ${ }^{1}$ at about $7 \mathrm{~km}$. Judging from the depth of the $\mathrm{K}$ horizon in the study area (which is between 5 and $8 \mathrm{~km}$ ), this would imply that the last large intrusion has already affected most of the crust above it.

With respect to lateral advective heat transport, a characteristic time scale for this study area is about $0.3 \mathrm{Ma}$, based on the time a fluid volume needs to traverse the entire domain through the upper reservoir (Burano unit). ${ }^{2}$ The regional heat flow anomaly and the $\mathrm{K}$ horizon are present in an area significantly larger than the study area, indicating that the heat source itself is of considerable size compared to the model domain. For such a large heat source, cooling on a time scale of 0.3 Ma can be neglected.

On the assumption of negligible permeability at and below the $\mathrm{K}$ horizon, a temperature of about $400-550^{\circ} \mathrm{C}$ agrees, in many areas of the world, with the maximum depth of seismicity in crustal rocks and is associated with the brittle/ductile transition zone (e.g. Ito 1999). This motivates the assumption of closure of connected pores and fractures by ductile creep at that depth. However, Pasquale et al. (2010) found a higher cut-off temperature for seismicity $\left(750^{\circ} \mathrm{C}\right)$ in the Tuscan regions with very high heat flow. This finding does not necessarily contradict the concept of having a brittle/ductile transition at a temperature of about $500{ }^{\circ} \mathrm{C}$ and may result from extraordinarily quick movements of magmatic intrusions into the crust (Pasquale et al. 2010).

In summary, the following assumptions have to be made with respect to the nature of the $\mathrm{K}$ horizon in order to justify the two boundary conditions at the $\mathrm{K}$ horizon: The $\mathrm{K}$ horizon is related to a (series of) large, hot intrusion(s), the last of which is more than 1.3Ma old. Due to the high temperature of about $500^{\circ} \mathrm{C}$ at the depth of the K horizon, all connected voids are closed by ductile creep, which results in a negligibly low permeability. The $\mathrm{K}$ horizon is possibly a thermometamorphic aureole, and the occurrence of trapped, high-pressure magmatic water in equilibrium with igneous melts is possible. However, this does not affect the assumption of very low permeability since this layer has no hydraulic coupling to the layers above.

The lateral temperature boundary conditions are obtained from a prior simulation of conductive heat transport with no-heat-flow lateral boundaries (top and bottom boundaries as described above). The pressure at the lateral boundaries increases hydrostatically with depth, starting with atmospheric pressure at the top boundary. This means that

\footnotetext{
${ }^{1}$ Estimate is based on an average thermal conductivity of $2.5 \mathrm{~W} /(\mathrm{m} \mathrm{K})$, a specific heat capacity of $950 \mathrm{~J} /(\mathrm{kg} \mathrm{K})$, and a density of $2500 \mathrm{~kg} / \mathrm{m}^{3}$.

2 Estimate is based on an average velocity of $3 \times 10^{-9} \mathrm{~m} / \mathrm{s}$ and a horizontal length of $28 \mathrm{~km}$.
} 
variation in topography may induce flow through permeable units of the model. Barelli et al. (2010) show borehole data of pressure vs. depth from the Bagnore and Piancastagnaio areas which are southwest and southeast of Monte Amiata, respectively. Both areas exhibit hydrostatic pressure distributions. Although the layers above the Burano formation have a low permeability, on a regional scale, recharge occurs locally at outcrops of the Burano (Romagnoli et al. 2010). However, within the model domain considered here, the Burano is always covered by the Ligurian unit and/or the TUaB.

\section{Hydrothermal simulations}

\section{Reference model}

Based on the reservoir structure, and rock and fluid properties, a reference model is calibrated using the available temperature observations in three boreholes (see Fig. 7). A few remarks regarding the calibration are necessary at this point:

1. All three boreholes (1-3) used for the calibration are located in the eastern part of the study area (see Fig. 9 for their locations). Hence, the results of the simulation are less reliable in the western area which is still actively being explored.

2. While Boreholes 1 and 3 give very good fits to the measured temperatures, the fit is not as good for Borehole 2. This is primarily as a result of the location of Borehole 2 in a corner of the structural model (see Fig. 9). Due to relatively poor seismic quality, interpretation of the shallower sedimentary units was difficult. The interpolation of the structural model fitted a compromise model between seismic and borehole log data. In this case, the boundary between the shallow geothermal aquifer and its cover unit is not accurately captured by the structural model at the location of Borehole 2.

The steady-state temperature distribution in the calibrated model in Fig. 8 reflects the general conductive heat flow from the $500^{\circ} \mathrm{C}$ isotherm at the $\mathrm{K}$ horizon to the surface. Advective heat transport occurs in the shallow and deep reservoir due to the regional groundwater flow and free convection. As such, the distribution of temperature is primarily influenced by the depth of the $\mathrm{K}$ horizon in the area and the direction and magnitude of fluid velocities. It should be noted that since the lateral temperature boundary conditions do not account for the effect of advective/convective heat transport (see the "Boundary conditions" section), this inevitably introduces a local inconsistency in the temperature distribution near the boundaries where advection/convection is relevant (see Fig. 8).

Lateral flow through the domain occurs mainly in the Burano formation due to its relatively high permeability (see Table 2). The general direction of flow is from NE to SSW as driven by the pressure gradient due to topographical variation. This can be seen in Fig. 10 which shows the Darcy flow at a depth $1 \mathrm{~km}$ below sea level and topography. In reality, the direction and magnitude of this regional flow can only be expected to be influenced by the regional trend in topography (through reservoir outcrops). There is a prominent outcrop, and recharge area, of the geothermal reservoir unit a few kilometres northeast of Monte Amiata (e.g. Fulignati et al. 2014). Note that Monte Amiata is northeast of the study area. The thermal springs in the Saturnia area, which lie south of the study area, have been attributed to one of the main outflows of the shallow geothermal 


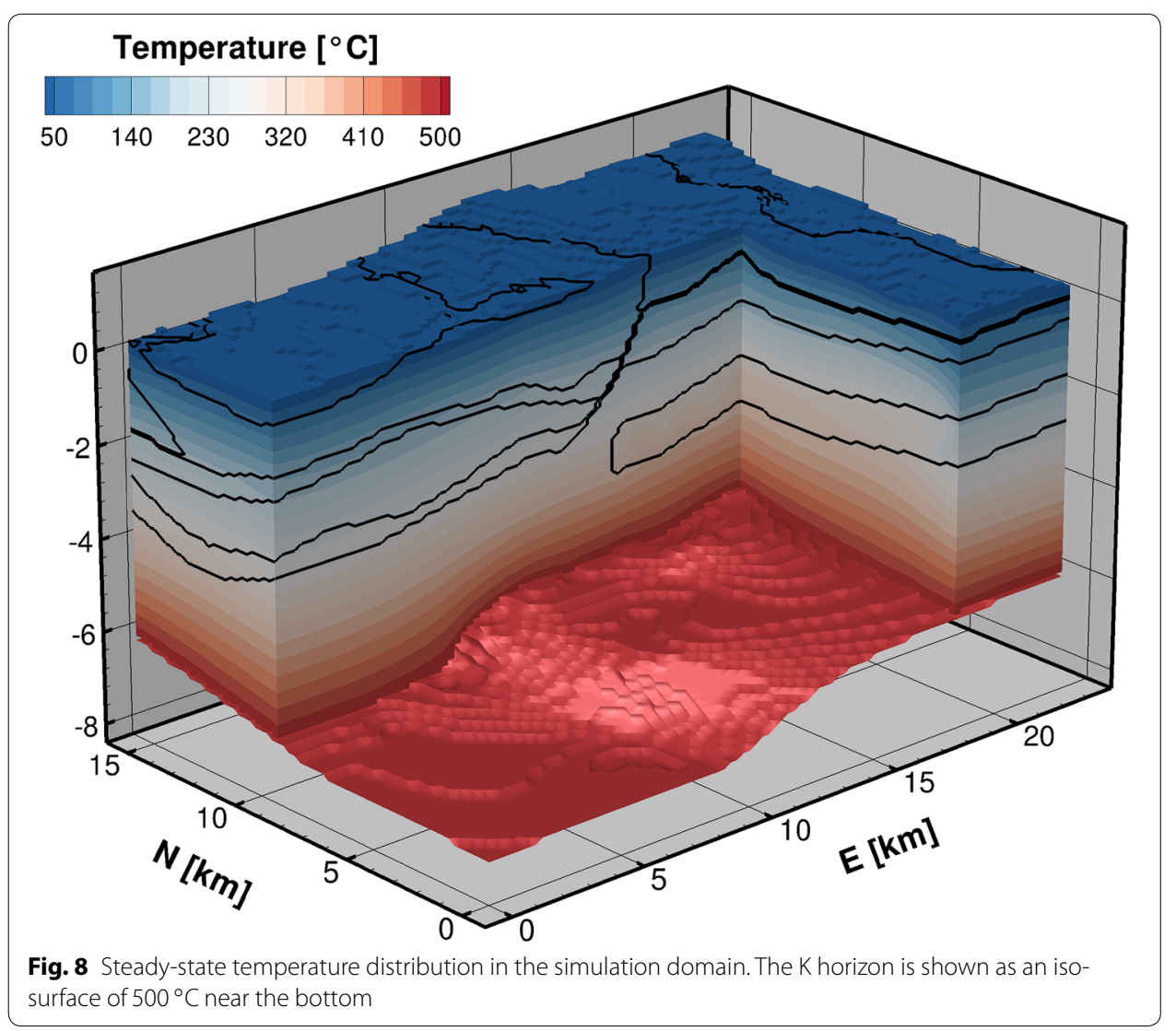

reservoir (e.g. Duchi et al. 1987; Guastaldi et al. 2014; Piccini et al. 2015). Hence, the NE to SSW lateral flow through the geothermal reservoir within the considered model domain is in accordance with the expected direction of regional flow of geothermal water in this area.

The specific surface heat flow is a typical near-surface observation which aids in the exploration of geothermal fields. In theory, it provides integral information of all the vertical heat transport processes from the heat source (i.e. the K horizon) to the surface. However, the shallower the process, the larger its influence on this near-surface measurement. Table 3 compares the predicted specific surface heat flow in the model to values measured in seven shallow and deep boreholes. Note that these measurements were not used to calibrate the model. The model is able to reproduce the trend in specific surface heat flow, though it tends to overpredict the values at the various locations. However, there are relatively large lateral fluctuations in the modelled surface heat flow of about $50 \mathrm{~mW} / \mathrm{m}^{2}$ (see Fig. 11). These are similar in magnitude to the average error calculated in Table 3.

The surface heat flow map is characterised by a distinct difference between the regions west and east of the major fault as well as smaller-scale variations and fluctuations (Fig. 9). These characteristics can be explained with the following points: 


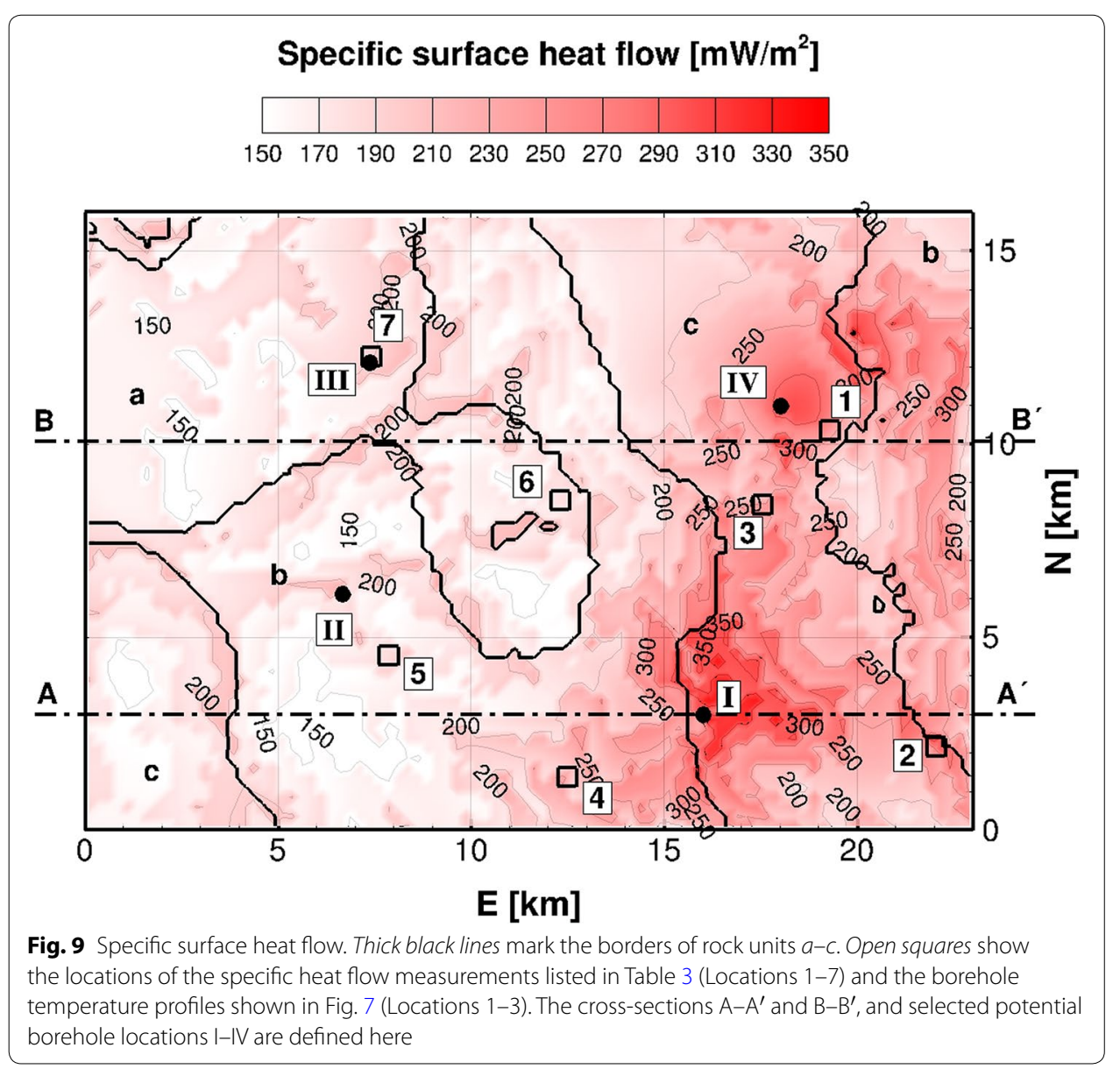

1. The depth of the K horizon affects surface heat flow in a general manner (i.e. generally higher heat flow in the east and lower in the west; compare Fig. 4 with Fig. 9);

2. The Burano formation is shallower and thicker in the east than in the west. A thick Burano unit of relatively high permeability increases vertical heat transport by advection. This can be seen on the cross-sections $A-\mathrm{A}^{\prime}$ and $\mathrm{B}-\mathrm{B}^{\prime}$ in Fig. 12 which show fluid velocity in the Burano unit. Particularly in $B-B^{\prime}$, the velocity vectors in the east often deviate from the horizontal, mainly as a result of the shape of the geological layer, but also due to convective flow. As such, the local maxima in surface heat flow east of the major fault correlate with the shallowest parts of the Burano unit (see Fig. 13). In the west, however, this correlation does not hold because the Burano is thinner and deeper, and flow velocities are lower (see Figs. 10,12) since permeability reduces with depth. Hence, the dominant heat transport mechanism in the west is conduction.

3. Variations in topography cause lateral variations in surface heat flow (Stein 1995). This is not corrected for in the model, yielding small-scale fluctuations in surface heat flow (topography is shown as the colour map in Fig. 10).

In Fig. 11, the processes described in this section have been summarised on the vertical cross-section A-A' (see Fig. 9 for its position). Generally, convective flow cells develop 


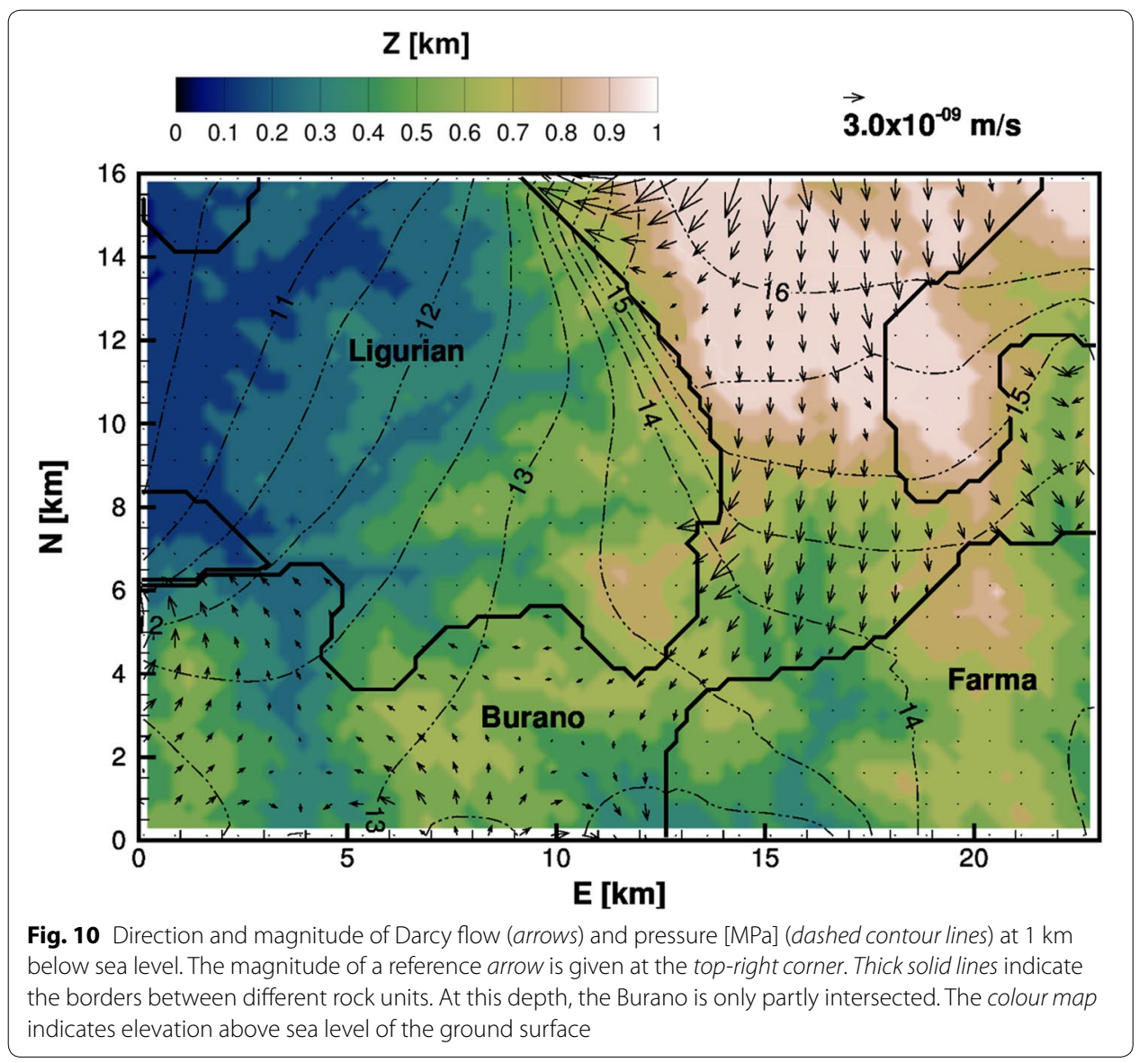

Table 3 Comparison of measured and modelled specific surface heat flow

\begin{tabular}{lllr}
\hline Location ID & $\begin{array}{l}\text { Measurement } \\
{\left[\mathrm{mW} / \mathrm{m}^{2}\right]}\end{array}$ & $\begin{array}{l}\text { Simulation } \\
{\left[\mathrm{mW} / \mathrm{m}^{2}\right]}\end{array}$ & $\begin{array}{l}\text { Difference } \\
{\left[\mathrm{mW} / \mathrm{m}^{2}\right]}\end{array}$ \\
\hline 1 & 224 & 265 & -41 \\
2 & 205 & 297 & -92 \\
3 & 248 & 247 & 1 \\
4 & 111 & 237 & -126 \\
5 & 250 & 188 & 62 \\
6 & 116 & 182 & -66 \\
7 & 270 & 200 & 70 \\
\hline
\end{tabular}

Locations 1-3 are from boreholes east of the major fault (i.e. Boreholes 1-3), while Locations 4-7 are shallow well measurements from the western part of the study area (see Fig. 9)

Average error (root mean square): 75

in the deep reservoir for which this is the most important heat transport mechanism, leading to the low vertical temperature gradient within this zone shown in Fig. 7i. Where the Burano unit is shallow (e.g. around $E=16 \mathrm{~km}$ in Fig. 11), the simulation model predicts relatively high temperatures very close to the ground surface. As discussed above, such areas are marked by high specific surface heat flows. However, Fig. 11 clearly shows how variations in the depth of the $\mathrm{K}$ horizon affect the general subsurface temperature 

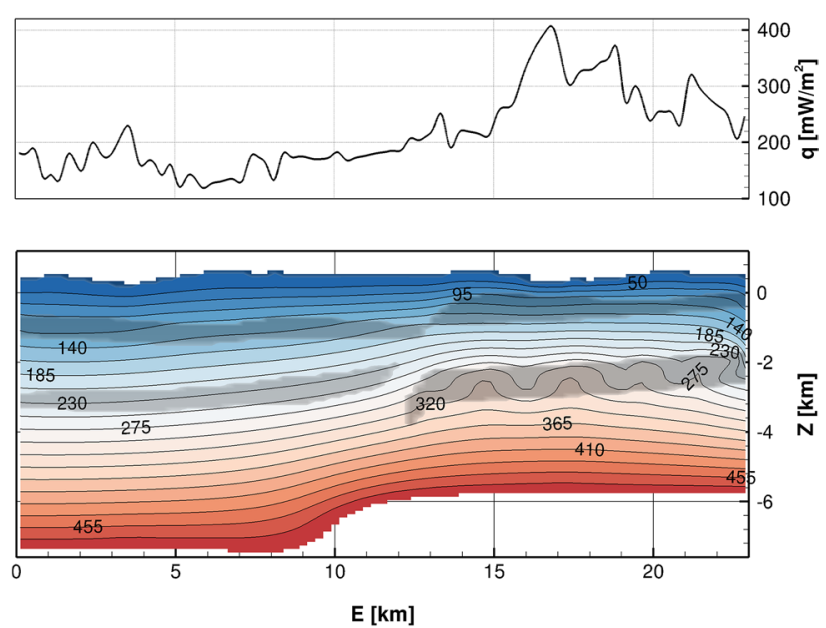

Temperature $\left[{ }^{\circ} \mathrm{C}\right]$

5095140185230275320365410455500

Fig. 11 Vertical cross-section along A-A' (see Fig. 9 for its position) showing specific surface heat flow (top) and temperature (bottom). The shaded areas represent reservoir layers of high permeability. In the shallow reservoir, conduction is superposed by topography-driven lateral advection, whereas convection is the dominant heat transport mechanism in the deep reservoir

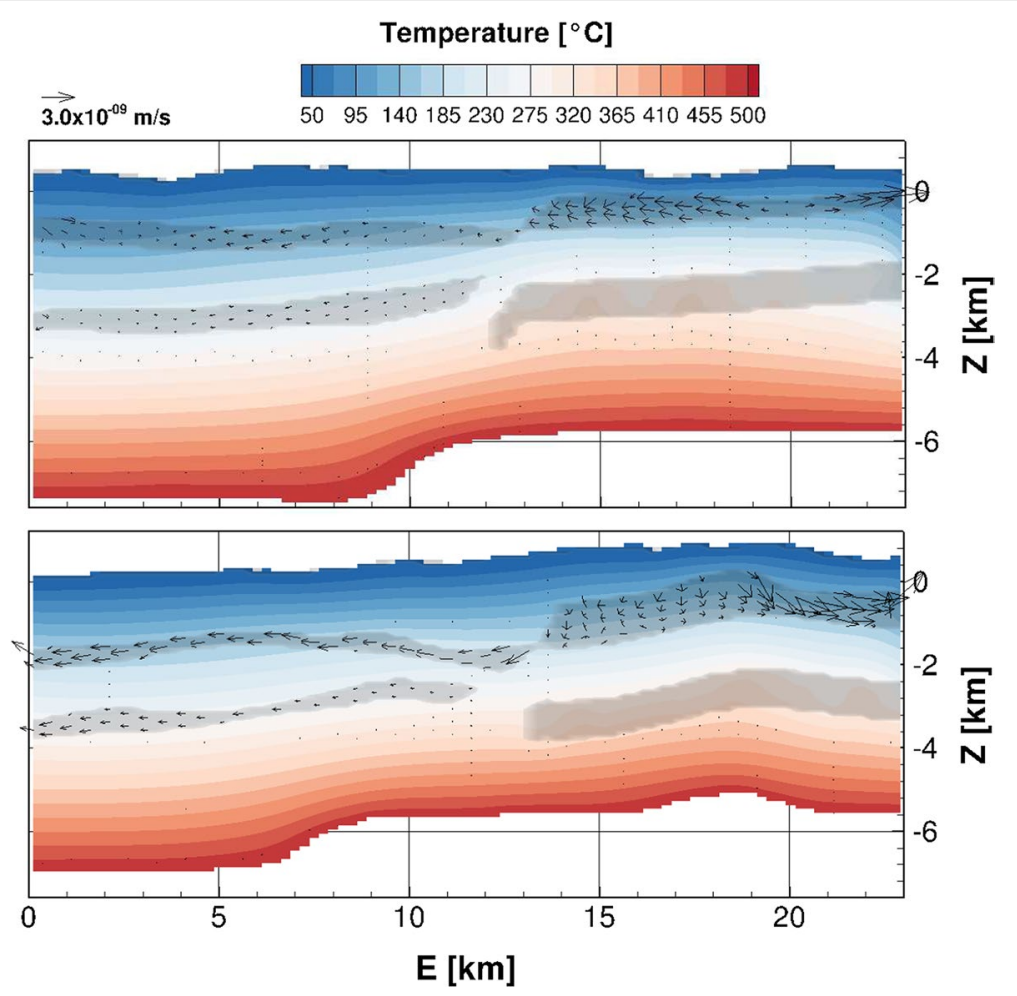

Fig. 12 Vertical cross-sections along $A-A^{\prime}$ (top) and $B-B^{\prime}$ (bottom) (see Fig. 9 for their positions) showing Darcy velocity (arrows) within the Burano unit. The magnitude of a reference arrow is given at the top-left corner. The shaded areas represent reservoir layers of high permeability. The velocity in the deep geothermal reservoir within the Farma unit is not shown to avoid clutter. The colouring represents temperature 


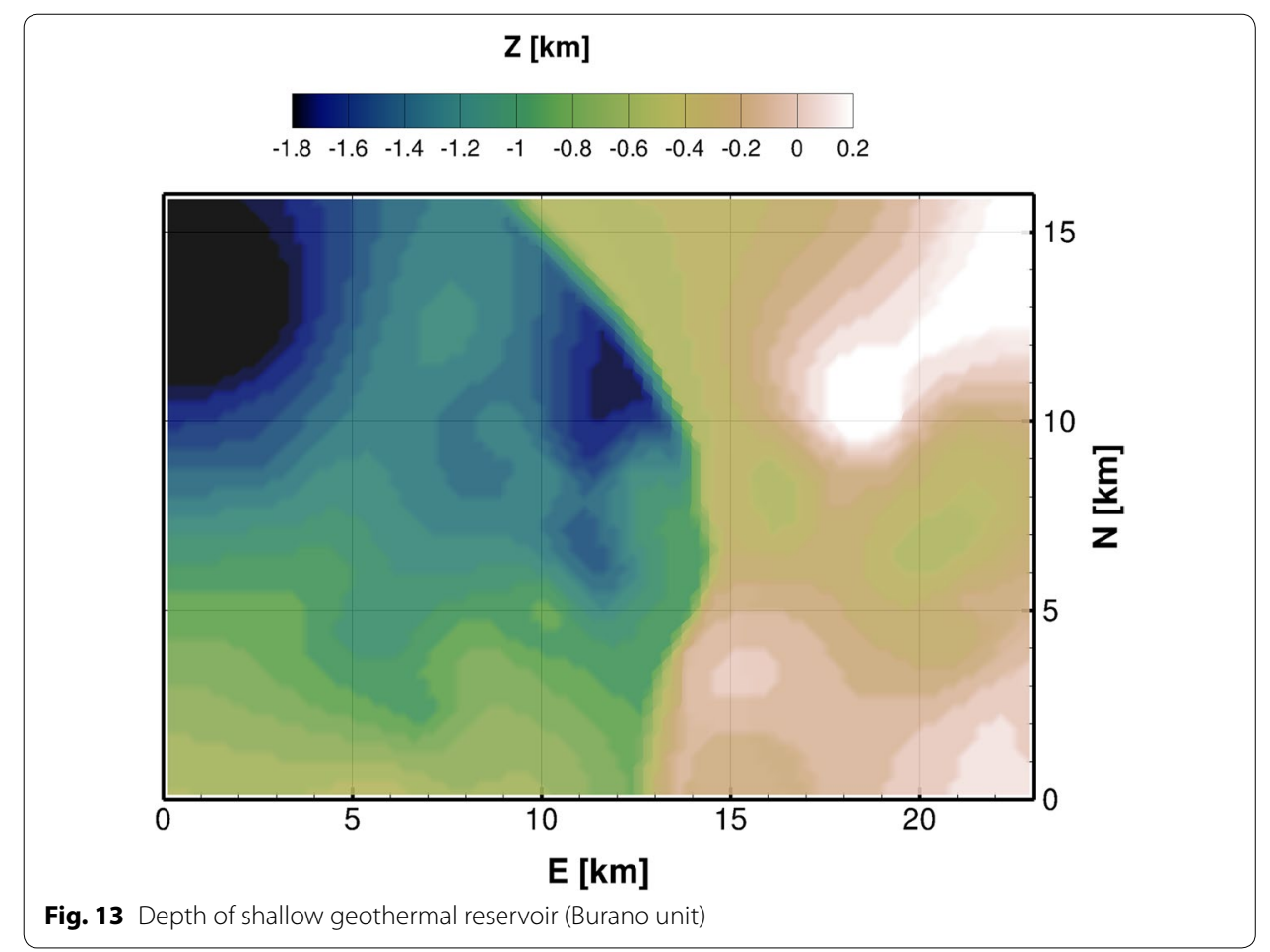

distribution. Much lower temperatures at a given depth are modelled in the western part of the cross-section $\mathrm{A}-\mathrm{A}^{\prime}$, where the $\mathrm{K}$ horizon is deepest. These areas also have the lowest surface heat flow values.

\section{Sensitivity study}

Based on the discussion in the "K horizon" section on the sources and reasons for uncertainty in depth and shape of the $\mathrm{K}$ horizon, several variations of the reference model are proposed here, representing either the extreme cases within the uncertainty range (with respect to depth and temperature) or an equally likely realisation of the shape of the $\mathrm{K}$ horizon based on differences in the extrapolation of the seismic data to areas where information is lacking. So-called indicators (i.e. representative model data) are selected to study model sensitivity to these variations.

\section{Selected indicators}

Four potential borehole locations (I-IV) have been selected for the purposes of this study (see Fig. 9 for their locations). It is assumed that the potential boreholes would all reach a depth of $3 \mathrm{~km}$ below sea level. The corresponding temperature profiles are available from the numerical model (Fig. 14). These profiles can be used in combination with specific surface heat flow as representative indicators to study the influence uncertainty in temperature, depth, and shape of the $\mathrm{K}$ horizon will have on the temperature distribution in the study area.

Figure 14 shows that the depth of the K horizon at the location of each borehole differs considerably. It is shallowest at Borehole IV and deepest at Borehole II. Additionally, 


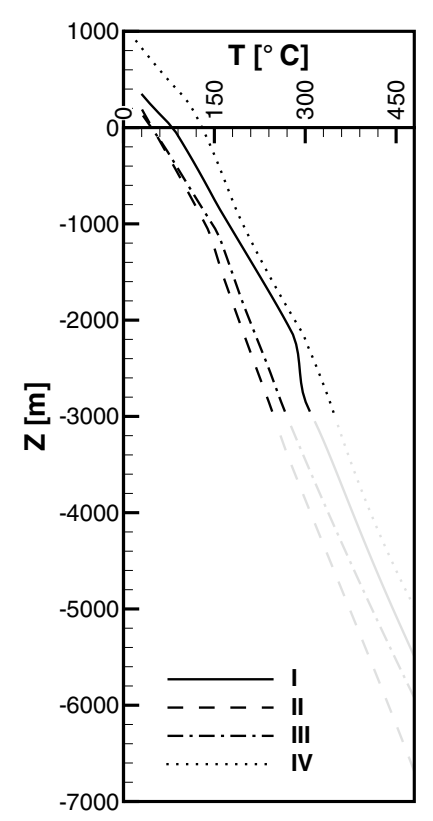

Fig. 14 Temperature-depth profiles of the four potential boreholes I-IV for the reference model. The assumption here is that the boreholes only reach a depth of $3 \mathrm{~km}$. The remainder of the temperature-depth profile is plotted in light grey

Boreholes I and IV are located east of the major fault, while Boreholes II and III are west of it.

\section{Variations}

For the reference model, a $\mathrm{K}$ horizon temperature of $500^{\circ} \mathrm{C}$ was used. In Variations 1 and 2, this temperature is set to $450^{\circ} \mathrm{C}$ and $400^{\circ} \mathrm{C}$, respectively. In Variations 3 and 4 , the temperature of the $\mathrm{K}$ horizon is kept at $500{ }^{\circ} \mathrm{C}$ but the overall position is shifted upwards and downwards by $300 \mathrm{~m}$. Finally, Variation 5 represents a differing interpretation of the shape of the K horizon.

1. Temperature of $\mathrm{K}$ horizon is $450^{\circ} \mathrm{C}$.

2. Temperature of $\mathrm{K}$ horizon is $400^{\circ} \mathrm{C}$.

3. K horizon is $300 \mathrm{~m}$ shallower. $^{3}$

4. $\mathrm{K}$ horizon is $300 \mathrm{~m}$ deeper.

5. Alternative (but equally likely) interpretation of shape of $\mathrm{K}$ horizon from the five available two-dimensional seismic profiles. In this case, the $\mathrm{K}$ horizon in the northwestern part of the domain is up to $500 \mathrm{~m}$ deeper (as shown in Fig. 15). Seismic data in this part of the model are unavailable, making an extrapolation, which is hardly supported by any data, necessary.

\footnotetext{
${ }^{3}$ On a technical note, it should be stated that the numerical model does not provide a converged, steady-state result for Variation 3. Instead, a transient simulation was run until no significant variation of the primary variables over time could be observed in chosen nodes of the model.
} 


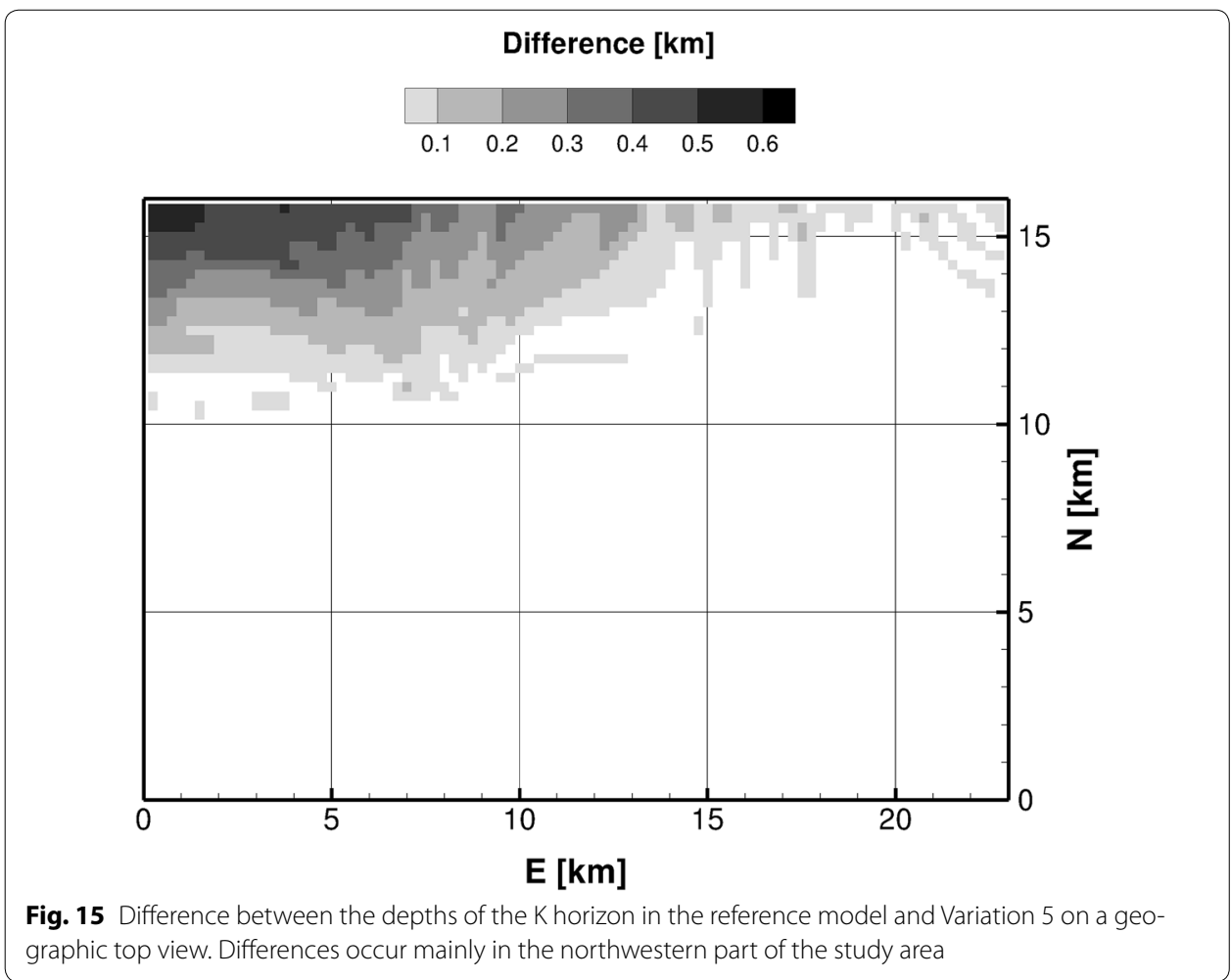

The effect of these variations on the temperature-depth profiles in Boreholes I-IV is shown in Fig. 16. The uncertainty in temperature of the $\mathrm{K}$ horizon $\left( \pm 50^{\circ} \mathrm{C}\right)^{4}$ yields higher temperature variations than uncertainty in depth $( \pm 300 \mathrm{~m})$. At a depth of $1 \mathrm{~km}$ below sea level, these result in variations ranging from \pm 7 to $\pm 15 \%$ of the reference temperatures (which, in this case, lie between 140 and $200^{\circ} \mathrm{C}$ ). Variation 5, which accounts for uncertainty in the shape of the $\mathrm{K}$ horizon, has a small influence on the borehole temperatures considered here. The borehole most affected by this variation is Borehole III which, unsurprisingly, is located within the northwestern area depicted in Fig. 15 where the differences between the depth of the K horizon in the reference case and Variation 5 are significant.

Generally, in Boreholes II and III, i.e. those in the west, the differences in temperature between the various scenarios propagate more or less linearly with depth. In Boreholes I and IV, however, the presence of convection in the deep reservoir tends to reduce or buffer the differences in temperature, particularly for the high-temperature scenarios.

The specific surface heat flow at the borehole locations (I-IV) for the various scenarios are listed in Table 4. These variations result in differences of up to $12 \%$ in Variations 1, 2, and 4 (with one exception, i.e. Borehole II and Variation 2, where the difference is $24 \%$ ). The differences are significantly lower in Variation 3, and lowest in Variation 5. This is the same trend as observed in the borehole temperature profiles. It may be worth noting that the differences in specific surface heat flow between the different variations are similar in magnitude to the difference between the observed and modelled surface heat flow (assuming the reference model) shown in Table 3.

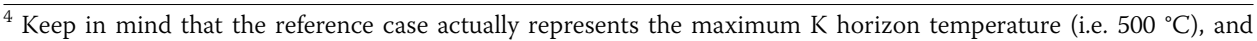
Variations 2 and 3 both have lower temperatures. 

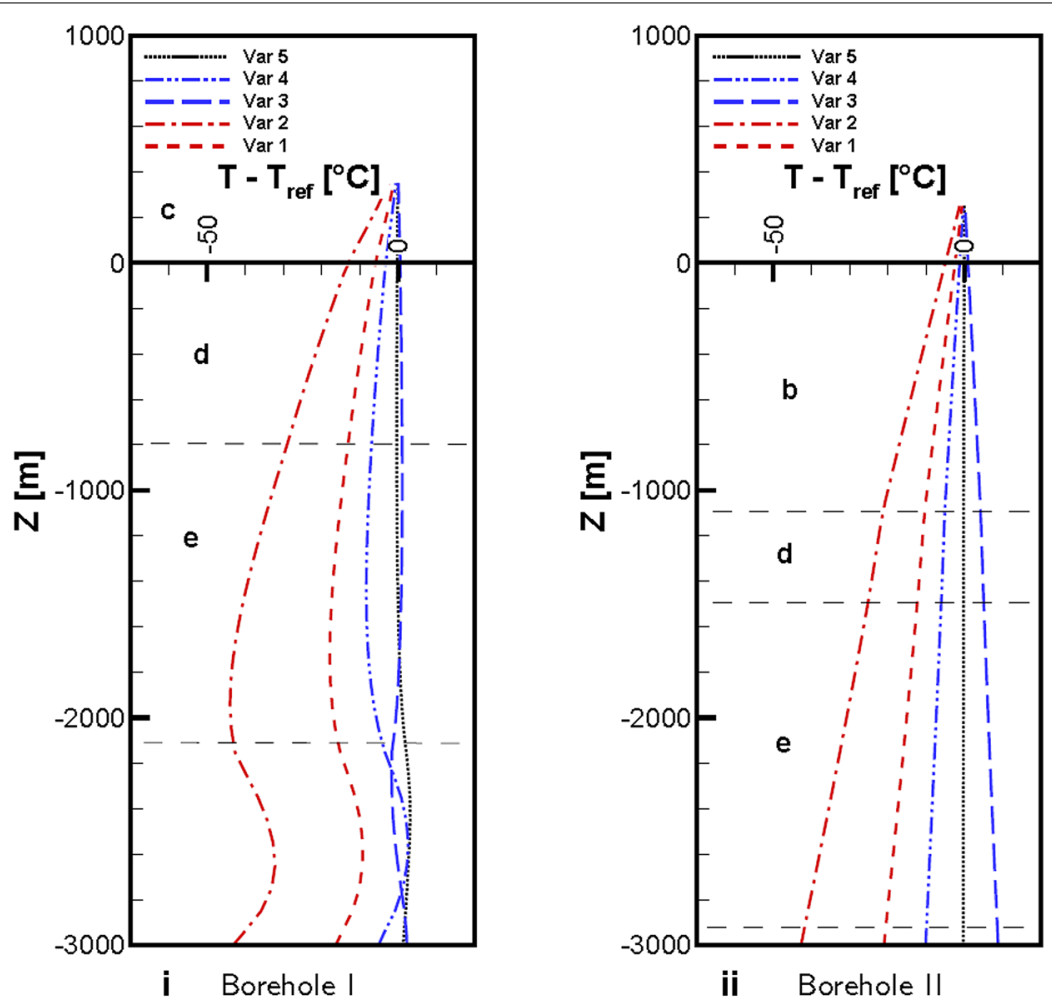

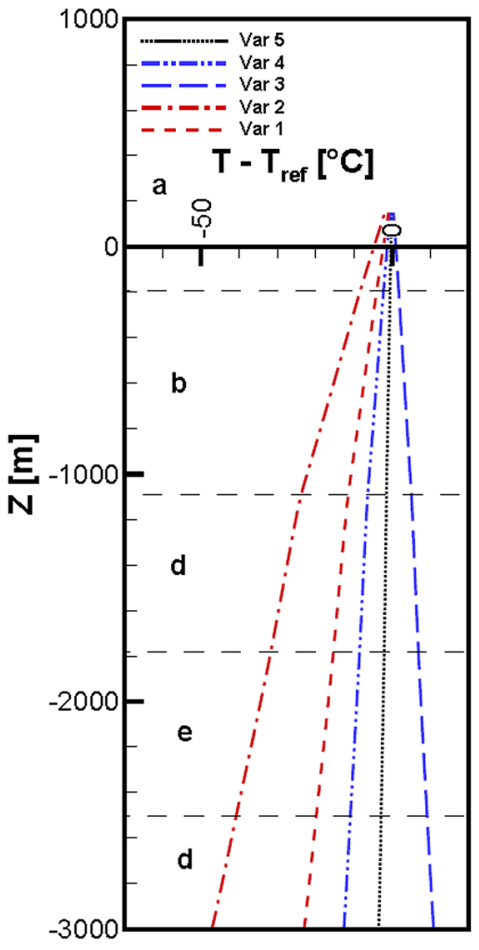

iii Borehole III

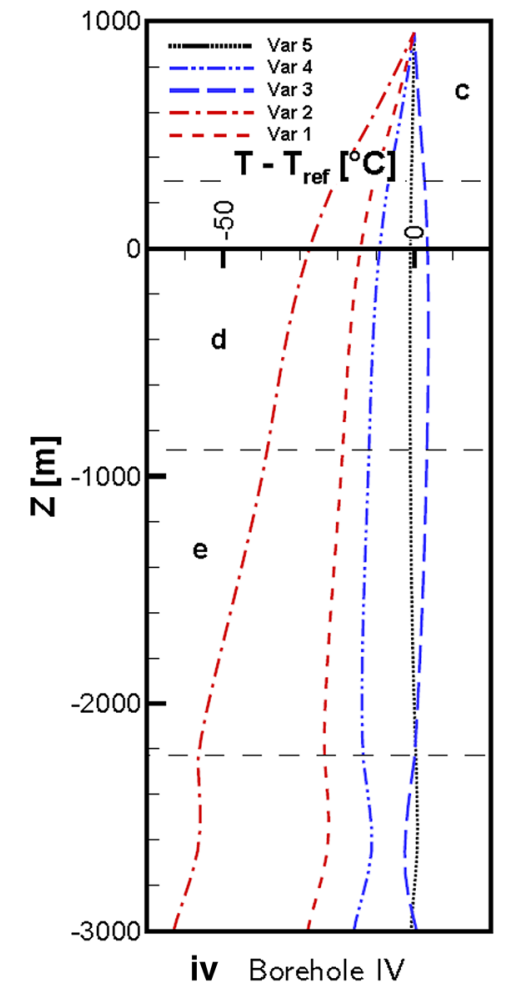

Fig. 16 Differences between borehole temperatures in the reference scenario and the variations at potential borehole locations (I-IV, i.e. i-iv, respectively). Temperature variations (Var. 1 and 2) are in red, depth variations (Var. 3 and 4) in blue, and the dotted line represents the shape variations (Var. 5). The various units, i.e. Pliocene (a), Ligurian (b), TUaB (c), Burano (d), Farma (e), and the deep reservoir, are separated by dashed horizontal lines 
Table 4 Specific surface heat flow at potential borehole locations

\begin{tabular}{lllllll}
\hline Borehole & \multicolumn{7}{l}{ Specific surface heat flow $\left[\mathrm{mW} / \mathbf{m}^{\mathbf{2}}\right]$} \\
\cline { 2 - 7 } & Ref. & Var. $\mathbf{1}$ & Var. $\mathbf{2}$ & Var. & Var. $\mathbf{3}$ & Var. 5 \\
\hline I & 319 & 289 & 254 & 323 & 303 & 318 \\
II & 184 & 169 & 128 & 190 & 160 & 184 \\
III & 199 & 183 & 165 & 206 & 190 & 197 \\
IV & 311 & 275 & 241 & 320 & 288 & 309 \\
\hline
\end{tabular}

\section{Discussion}

The simulations presented in the "Hydrothermal simulations" section which model the natural state of a geothermal area in Tuscany are assumed to be representative of other Tuscan geothermal reservoirs, with the exception of the steam reservoirs. In particular, a common feature of most geothermal reservoirs in the area is the $K$ horizon. Assuming that the K horizon does indeed represent a constant temperature boundary condition at the bottom of these reservoirs, its depth, shape, and temperature then are defining characteristics of the reservoirs.

In the simulations of the study area, the $\mathrm{K}$ horizon dominates the temperature distribution and is one of the strongest indicators for geothermal potential (see, e.g. Fig. 11). This statement can be generalised for other Tuscan geothermal reservoirs. Hence, a reasonable effort at delineating the characteristic features of the $\mathrm{K}$ horizon appears to be a prerequisite in the exploration of such a geothermal area.

In accordance with this reasoning, the surface heat flow of the study area correlates in a general manner to the structure of the $\mathrm{K}$ horizon in that there is a clear demarcation between the areas where the $\mathrm{K}$ horizon is relatively shallow (the east) and areas where it is significantly deeper (the west). However, local maxima in the surface heat flow correlate with the shape of the Burano unit (see Figs. 9, 13) within which topography-driven advective heat transport takes place at relatively shallow depths. These maxima in surface heat flow are good indicators of structural highs of the shallow reservoir.

Even if the geometry of the K horizon were relatively well known (e.g. from reflection seismics), a certain degree of uncertainty would persist. In the present study, uncertainties of $\pm 50^{\circ} \mathrm{C}$ for the temperature of the K horizon and $\pm 300 \mathrm{~m}$ for its depth have been assumed. Even though the former value can be limited by temperature measurements in deep boreholes and the latter value is smaller the shallower the $\mathrm{K}$ horizon is, both uncertainties can be regarded as more or less representative for the Tuscan area. Uncertainty in the exact shape of the horizon is more case specific and, in this particular case, does not significantly affect the reservoir studied here.

These uncertainties translate into uncertainty in the potential borehole temperature profiles (Fig. 16) and specific surface heat flows (Table 4), with the uncertainty in K horizon temperature having the biggest impact, followed by uncertainty in depth. This is a reasonable finding for conductive geothermal regimes for which the depth uncertainty is equivalent to an uncertainty in $\mathrm{K}$ horizon temperature of about $21^{\circ} \mathrm{C}$ (assuming a geothermal gradient of $70 \mathrm{~K} / \mathrm{km}$, taken from Borehole II), which is less than half the abovementioned uncertainty in temperature. 
Interestingly, the values (of both borehole temperatures and surface heat flow) in Variation 3 (shallower $\mathrm{K}$ horizon) are comparatively close to the reference case. Convection in the deep reservoir changes the geothermal gradient above it in a manner that is dependent on density differences (and hence pressure and temperature). In the cases studied, uncertainty in temperature and surface heat flow was reduced above the strongly convective layer.

Figure 17 compares temperature isolines of the reference scenario and Variation 3. It shows that in the deep reservoir, i.e. the convective regime, the temperature in the borehole depends very strongly on the positions of the convective cells and whether the selected borehole location happens to cross an upflow or downflow region. This makes it more difficult to extrapolate shallow data across such a layer to the K horizon, e.g. when inferring its temperature by extrapolation of borehole temperature profiles.

Obviously, there are other sources of uncertainty which have not been discussed here. For example, uncertainty in the geometry of the various rock units and their permeabilities, particularly the shallow and deep reservoirs, may result in uncertainty in the importance of advection and convection. A good example for this is the stacking of the Burano and Farma units west of the major fault (see Fig. 3). In an alternative interpretation by Riedel et al. (2015), this stacking does not exist. Instead, the Burano unit west of the major fault is considered to be very thick, which may affect the thermal regime in that area. These sources of uncertainty can interact with the sources of uncertainty related

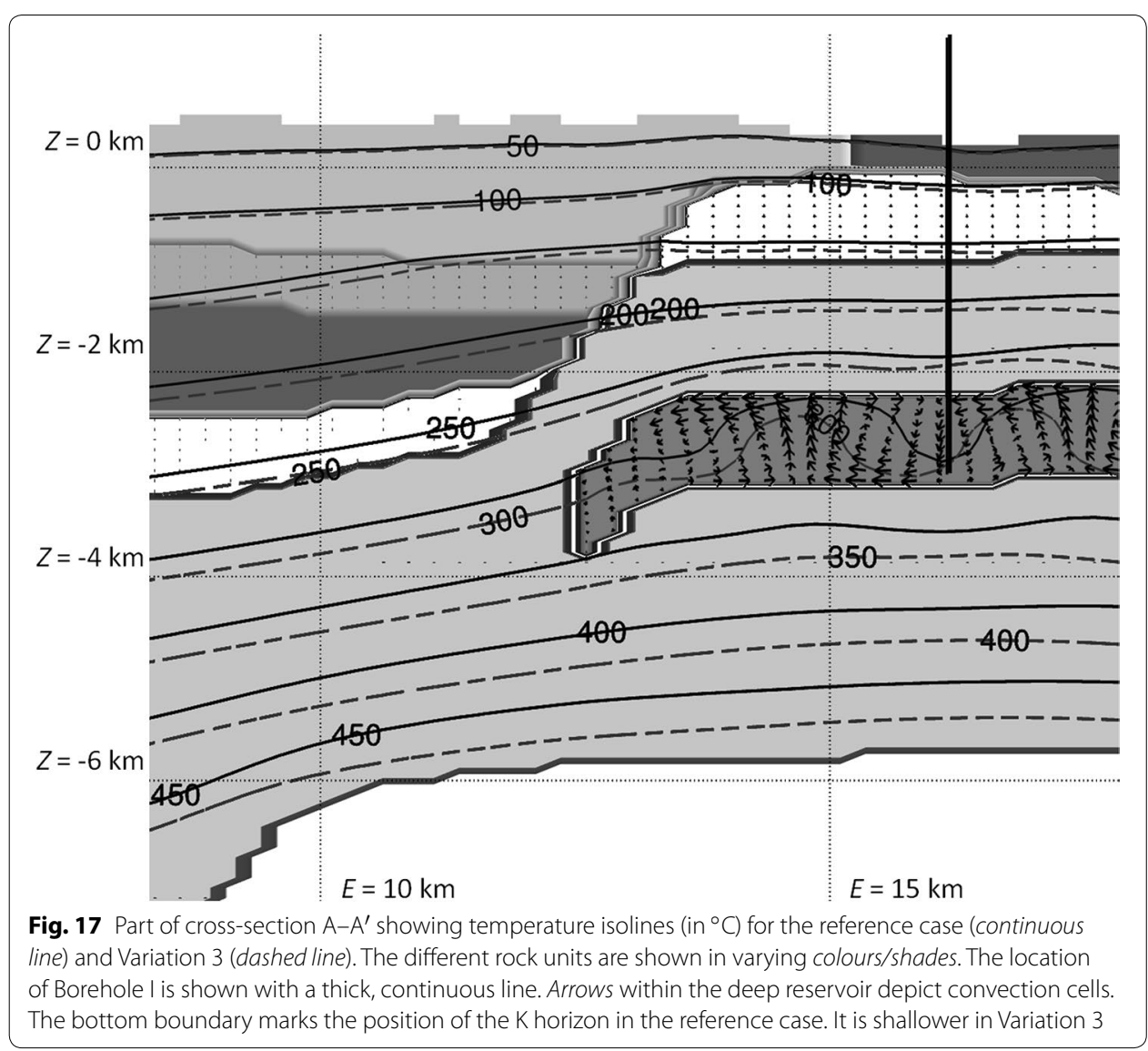


to the crustal heat source, and their relative relevance would depend on the question at hand. While the $\mathrm{K}$ horizon dominates temperature distribution, uncertainty in the permeability of the geothermal reservoir is essential when considering flow rate uncertainty for a potential exploitation borehole.

For the study area, it is obvious that the region east of the main fault provides a much greater potential for geothermal exploitation than in the west. This is due to (1) the depth of the K horizon (see Fig. 4), (2) the thickness and depth of the permeable Burano layer (see Figs. 11 and 13, respectively), and (3) the presence of a deeper permeable layer in the east (see Fig. 3). Nonetheless, profitable geothermal exploitation is possible in the western part, albeit more risky given the lower temperatures in Boreholes II and III (Fig. 14) and their ranges of uncertainty (Fig. 16). Thus, a better characterisation of the area west of the main fault (i.e. further exploration) seems more necessary than east of it.

\section{Conclusions}

A hydrothermal simulation model of the geothermal reservoir in southern Tuscany presented in this article highlights the importance of the position, temperature, and structure of the K horizon in the evaluation of such an area for geothermal use.

Many sources of uncertainty in geothermal exploration are site specific. Uncertainty in depth and temperature of the $\mathrm{K}$ horizon is expected to be common to most reservoirs in Tuscany. In this regard, the study predicts the highest degree of uncertainty to stem from uncertainty in the temperature of the K horizon. Temperature measurements in deep boreholes can effectively reduce this uncertainty. In conductive regimes, surface heat flow and temperatures in shallow boreholes also provide relevant information about the $\mathrm{K}$ horizon. In the presence of advection/convection, this information is altered.

Lateral advection in relatively shallow reservoir rock layers leads to local maxima and minima in surface heat flow. The presence of a layer within which strong convection occurs strongly increases upward heat transport in the layer and tends to complicate the propagation of uncertainty from the $\mathrm{K}$ horizon.

For this specific study area, further exploration of the western part is necessary to increase the probability of a successful geothermal operation in that area.

Authors' contributions

All authors contributed to round-table discussions according to their respective areas of expertise and experience to the interpretation of data and development of the basic concepts and assumptions which constitute the reservoir model. AE set up the numerical model, conducted and interpreted numerical simulations, and drafted the manuscript. JN contributed to the structural and geological model, numerical simulations, and drafting of the manuscript. GM drafted a significant part of the manuscript and contributed to every aspect of the study, including general coordination. ID, RB, WR, CC, and GM conceived of the study and contributed their experience to the realistic conceptualisation of the model. RP analysed petrophysical data, conducted laboratory measurements, and drafted part of the manuscript. MT and WR processed geophysical data (including seismic data) and set up the structural model. All authors read and approved the final manuscript.

\footnotetext{
Author details

${ }^{1}$ Institute for Applied Geophysics and Geothermal Energy, E.ON Energy Research Center, RWTH Aachen University, Mathieustrreet 10, 52074 Aachen, Germany. ${ }^{2}$ Department of Earth Science and Engineering, Imperial College, South Kensington Campus, SW7 2AZ London, UK. ${ }^{3}$ Enel Green Power, Via Andrea Pisano 120, 56122 Pisa, Italy. ${ }^{4}$ Department for Applied Geophysics, Institute for Geosciences, Christian-Albrechts-University, Kiel, Germany. ${ }^{5}$ Geophysica Beratungsgesellschaft mbH, Aachen, Germany.
} tists have contributed with numerous very helpful discussions on the reservoir properties and behaviour. This study is part of the MeProRisk-II project and is funded by the German Federal Ministry of Economy (BMWi) under Grant 0325389. 


\section{Competing interests}

The authors declare that they have no competing interests.

Received: 5 October 2015 Accepted: 14 March 2016

Published online: 31 March 2016

\section{References}

Baiocchi A, Dragoni W, Lotti F, Luzzi G, Piscopo V. Outline of the hydrogeology of the Cimino and Vico volcanic area and of the interaction between groundwater and lake Vico (Lazio Region, central Italy). Boll Soc Geol Ital. 2006;125:187-202.

Barelli A, Palamà A. A new method for evaluating formation equilibrium temperature in holes during drilling. Geothermics. 1981;10(2):95-102. doi:10.1016/0375-6505(81)90015-8.

Barelli A, Ceccarelli A, Dini I, Fiordelisi A, Giorgi N, Lovari F, Romagnoli P. A review of the Mt. Amiata geothermal system (Italy). In: Proceedings World Geothermal Congress 2010, Bali, Indonesia, 25-29 April 2010.

Batini F, Brogi A, Lazzarotto A, Liotta D, Pandeli E. Geological features of Larderello-Travale and Mt. Amiata geothermal areas (southern Tuscany, Italy). Episodes. 2003;26(3):239-44.

Bellani S, Brogi A, Lazzarotto A, Liotta D, Ranalli G. Heat flow, deep temperatures and extensional structures in the Larderello Geothermal Field (Italy): constraints on geothermal fluid flow. J Volcanol Geotherm Res. 2004;132(1):15-29. doi:10.1016/s0377-0273(03)00418-9.

Bellani S, Magro G, Brogi A, Lazzarotto A, Liotta D. Insights into the Larderello geothermal field: structural setting and distribution of thermal and ${ }^{3} \mathrm{He}$ anomalies. In: Proceedings world geothermal congress, Antalya, 24-29 April 2005.

Bertini G, Cappetti G, Dini I, Lovari F. Deep drilling results and updating of geothermal knowledge on the Monte Amiata area. Proc World Geotherm Congress. 1995;2:1283-6.

Bertini G, Casini M, Ciulli B, Ciuffi S, Fiordelisi A. Data revision and upgrading of the structural model of the Travale geothermal field (Italy). In: Proceedings world geothermal congress, Antalya, Turkey, 24-29 April 2005. 2005.

Brogi A. Neogene extension in the Northern Apennines (Italy): insights from the southern part of the Mt. Amiata geothermal area. Geodinamica Acta. 2006;19(1):33-50. doi:10.3166/ga.19.33-50.

Brogi A. Kinematics and geometry of Miocene low-angle detachments and exhumation of the metamorphic units in the hinterland of the Northern Apennines (Italy). J Struct Geol. 2008a;30(1):2-20. doi:10.1016/j.jsg.2007.09.012.

Brogi A. The structure of the Monte Amiata volcano-geothermal area (Northern Apennines, Italy): Neogene-Quaternary compression versus extension. Int J Earth Sci. 2008b;97(4):677-703. doi:10.1007/s00531-007-0191-1.

Brogi A. The Triassic and Palaeozoic successions drilled in the Bagnore geothermal field and Poggio Nibbio area (Monte Amiata, Northern Apennines, Italy). Bollettino Della Societa Geologica Italiana. 2008c;127(3):599-613.

Bücker C, Rybach L. A simple method to determine heat production from gamma-ray logs. Marine Petrol Geol 1996;13(4):373-375. doi:10.1016/0264-8172(95)00089-5. Nordic symposium on petrophysics in computer modelling of reservoir and basin processes, Gothenbrug, Sweden, May 31-June 01, 1994.

Cameli GM, Dini I, Liotta D. Upper crustal structure of the Larderello geothermal-field as a feature of postcollisional extensional tectonics (southern Tuscany, Italy). Tectonophysics. 1993;224(4):413-23. doi:10.1016/0040-1951(93)90041-H.

Cameli GM, Dini I, Liotta D. Brittle/ductile boundary from seismic reflection lines of southern Tuscany (Northern Apennines, Italy). Memorie della Società Geologica Italiana. 1998;52:153-62.

Ceroti M, Fiordelisi A, Fulignati P, Marianelli P, Sbrana A, Scazzola S. Integrated approach for a successful geothermal wells location in the Mt. Amiata Area (Southern Tuscany). In: Proceedings world geothermal congress, Melbourne, Australia, 19-25 April 2015.

Claps P, Giordano P, Laguardia G. Spatial distribution of the average air temperatures in Italy: quantitative analysis. J Hydrol Eng. 2008;13(4):242-9. doi:10.1061/(ASCE)1084-0699.

Clauser C. Thermal storage and transport properties of rocks, ii: thermal conductivity and diffusivity. In: Gupta H, editor. Encyclopedia of solid earth geophysics. 2nd ed. Berlin: Springer; 2011. p. 1431-48.

Clauser C. Numerical simulation of reactive flow in hot aquifers: SHEMAT and processing SHEMAT. Berlin: Springer; 2003. doi:10.1007/978-3-642-55684-5.

Vedova Della B, Vecellio C, Bellani S, Tinivella U. Thermal modelling of the Larderello geothermal field (Tuscany, Italy). Int J Earth Sci. 2008:97(2):317-32. doi:10.1007/s00531-007-0249-0.

Dini A, Innocenti F, Rocchi S, Tonarini S, Westerman DS. The magmatic evolution of the late Miocene laccolith-plutondyke granitic complex of Elba Island, Italy. Geol Mag. 2002;139:257-79. doi:10.1017/S0016756802006556.

Dini A, Gianelli G, Puxeddu M, Ruggieri G. Origin and evolution of Pliocene-Pleistocene granites from the Larderello geothermal field (Tuscan Magmatic Province, Italy). Lithos. 2005;81(1-4):1-31. doi:10.1016/j.lithos.2004.09.002.

Doveton JH. Geologic log analysis using computing methods. In: AAPG computer applications in geology, no. 2. Tulsa, OK. 1994.

Duchi V, Minissale AA, Prati F. Chemical-composition of thermal springs, cold springs, streams, and gas vents in the Mt Amiata geothermal region (Tuscany, Italy). J Volcanol Geotherm Res. 1987;31(3-4):321-32. doi:10.1016/0377-0273(87)90075-.

Ellis DV, Singer SM. Well logging for earth scientists. Dordrecht: Springer; 2007.

Erbas K. Eine universelle Methode zur Bestimmung der Wärmeleitfähigkeit aus Aufheizkurven konstant geheizter Zylinderquellen. berlin: Technische Universität Berlin; 2001.

Frondini F, Caliro S, Cardellini C, Chiodini G, Morgantini N. Carbon dioxide degassing and thermal energy release in the Monte Amiata volcanic-geothermal area (Italy). Appl Geochem. 2009;24(5):860-75. doi:10.1016/j. apgeochem.2009.01.010.

Fulignati P, Marianelli P, Sbrana A, Ciani V. 3D geothermal modelling of the Mount Amiata hydrothermal system in Italy. Energies. 2014;7(11):7434-53. doi:10.3390/en7117434 
Gianelli G, Manzella A, Puxeddu M. Crustal models of the geothermal areas of southern Tuscany (Italy). Tectonophysics. 1997;281(3-4):221-39. doi:10.1016/S0040-1951(97)00101-7.

Gianelli G, Puxeddu M, Batini F, Bertini G, Dini I, Pandeli E, Nicolich R. Geological model of a Young volcanoplutonic system: the geothermal region of Monte Amiata (Tuscany, Italy). Geothermics. 1988;17:719-34. doi:10.1016/0375-6505(88)90033-8.

Guastaldi E, Graziano L, Liali G, Brogna FNA, Barbagli A. Intrinsic vulnerability assessment of Saturnia thermal aquifer by means of three parametric methods: SINTACS GODS and COP. Environ Earth Sci. 2014;72(8):2861-78. doi:10.1007/ s12665-014-3191-

Hajto M. Resources and Possible Directions of Use of Geothermal Waters in the Polish Part of the Eastern Carpathian. In: Proceedings world geothermal congress, Melbourne, 19-25 April 2015.

Hartmann A, Rath V, Clauser C. Thermal conductivity from core and well log data. Int J Rock Mech Min Sci. 2005;42(7-8): 1042-1055. doi:10.1016/j.jirmms.2005.05.01. European Commiss. 2nd Euroconference on Rock Physics and Rock Mechanics, Bad Honnef, Germany, 2000.

Hartmann A, Pechnig R, Clauser C. Petrophysical analysis of regional-scale thermal properties for improved simulations of geothermal installations and basin-scale heat and fluid flow. Int J Earth Sci. 2008:97(2):421-433. doi:10.1007/s00531007-0283. 6th International Meeting on Heat Flow and the Lithosphere Structure, Bykov. Czech Republic, Jun 5-10, 2006.

Horner DR. Pressure build-up in wells. In: Proceedings third world petroleum congress, Section II, Preprint 7. Leiden: E.J. Brill; 1951.

Innocenti F, Serri G, Ferrara G, Manetti P, Tonarini S. Genesis and classification of rocks of the tuscan magmatic province: thirty years after Marinelli's model. Acta Vulcanol. 1992;2:247-65.

Ito K. Seismogenic layer, reflective lower crust, surface heat flow and large inland earthquakes. Tectonophysics. 1999;306(3):423-33. doi:10.1016/50040-1951(99)00069-4.

Jiang X-W, Wang X-S, Wan L. Semi-empirical equations for the systematic decrease in permeability with depth in porous and fractured media. Hydrogeol J. 2010;18(4):839-50. doi:10.1007/s10040-010-0575-3.

Lajaunie C, Courrioux G, Manuel L. Foliation fields and 3D cartography in geology: principles of a method based on potential interpolation. Math Geol. 1997;29(4):571-84. doi:10.1007/BF02775087.

Liotta D, Ranalli G. Correlation between seismic reflectivity and rheology in extended lithosphere: southern Tuscany, inner Northern Apennines, Italy. Tectonophysics 315(1-4), 109-122. 1999. doi:10.1016/S0040-1951(99)00292-9. 8th Annual Workshop of the International Lithosphere Program Task Force on Origin of Sedimentary Basins, Sicily Italy, 1997.

Lugli S. Timing of post-depositional events in the Burano formation of the Secchia valley (Upper Triassic, Northern Apennines), clues from gypsum-anhydrite transitions and carbonate metasomatism. Sediment Geol. 2001;140(1-2):10722. doi:10.1016/50037-0738(00)00174-3.

Manning C, Ingebritsen S. Permeability of the continental crust: implications of geothermal data and metamorphic systems. Rev Geophys. 1999;37(1):127-50. doi:10.1029/1998RG900002.

Pape H, Clauser C, Iffland J. Variation of permeability with porosity in sandstone diagenesis interpreted with a fractal pore space model. Pure Appl Geophys. 2000;157(4):603-19. doi:10.1007/PL00001110.

Pasquale V, Chiozzi P, Verdoya M. Tectonothermal processes and mechanical strength in a recent orogenic belt: Northern Apennines. J Geophys Res Solid Earth. 2010;115(B3):03301. doi:10.1029/2009JB006631.

Pasquale V, Verdoya M, Chiozzi P. Heat flow and geothermal resources in northern Italy. Renew Sustain Energy Rev. 2014;36:277-85. doi:10.1016/.j.rer.2014.04.075.

Peccerillo A. Multiple mantle metasomatism in central-southern Italy: geochemical effects, timing and geodynamic implications. Geology. 1997;27(4):315-8.

Piccini L, De Waele J, Galli E, Polyak VJ, Bernasconi SM, Asmerom Y. Sulphuric acid speleogenesis and landscape evolution: Montecchio cave, Albegna river valley (Southern Tuscany, Italy). Geomorphology. 2015;229(SI):134-43. doi:10.1016/j. geomorph.2014.10.00.

Popov YA, Pribnow DFC, Sass JH, Williams CF, Burkhardt H. Characterization of rock thermal conductivity by high-resolution optical scanning. Geothermics. 1999;28(2):253-76. doi:10.1016/S0375-6505(99)00007-3.

Rath V, Wolf A, Buecker HM. Joint three-dimensional inversion of coupled groundwater flow and heat transfer based on automatic differentiation: sensitivity calculation, verification, and synthetic examples. Geophys J Int. 2006;167(1):453-66. doi:10.1111/j.1365-246X.2006.03074.X.

Riedel M, Dutsch C, Alexandrakis C, Dini I, Ciuffi S, Buske S. Seismic depth imaging of a geothermal system in Southern Tuscany. Geophys Prospect. 2015;63(4):957-74. doi:10.1111/1365-2478.12254.

Romagnoli P, Arias A, Barelli A, Cei M, Casini M. An updated numerical model of the Larderello-Travale geothermal system, Italy. Geothermics. 2010;39(4):292-313. doi:10.1016/j.geothermics.2010.09.010. (Special Issue on the Sustainable Utilization of Geothermal Energy)

Rossetti F, Tecce F, Billi A, Brilli M. Patterns of fluid flow in the contact aureole of the Late Miocene Monte Capanne pluton (Elba Island, Italy): the role of structures and rheology. Contrib Mineral Petrol. 2007;153(6):743-60. doi:10.1007/ s00410-006-0175-3.

Roux B, Sanyal SY, Brown SL. An improved approach to estimating true reservoir temperature from transient temperature data. Proceedings fifth workshop on geothermal reservoir engineering. Stanford: Stanford University; 1979. p. $343-54$.

Schlumberger. Log interpretation principles/applications, 7th edn. Sugar Land: Schlumberger; 1998.

Sekiguchi K. A method for determining terrestrial heat-flow in oil basinal areas. Tectonophysics. 1984;103(1-4):67-79. doi:10.1016/0040-1951(84)90075-1.

Serra O. Fundamentals of well-log interpretation, vol. 1. Amsterdam: Elservier; 1984.

Snow DT. Rock fracture spacings, openings, and porosities. J Soil Mech Found Div. 1968;94(1):73-92. doi:10.1016/0040-1951(84)90075-1. 
Spinelli R, Casini M, Costantino N, Giudetti G, Ciuffi S, Dini A. Anatomy of granite intrusions in the Travale geothermal field (Italy): a first geochemical-petrographic-spectral gamma ray log approach. In: Proceedings world geothermal congress, Melbourne, 19-25 April 2015.

Stein CA. In: Ahrens TJ, editor. Heat flow of the earth. Washington, DC: American Geophysical Union; 1995. p. 144-58. doi:10.1029/RF001p0144.

Thorwart M, Behrendt R, Dreiling J, Holzrichter N, Rabbel W, Niederau J, Ebigbo A, Marquart G, Dini I, Ciuffi S. Geothermal assessment based on seismic, magnetotelluric and potential field analysis and hydrothermal forward modeling —an example from Southern Tuscany (Italy). In: Proceedings world geothermal congress, 19-24 April 2015, AustraliaNew Zealand; 2015.

van Bergen MJ. Polyphase metamorphic sedimentary xenoliths from Mt Amiata volcanics (Central Italy) —evidence for a partially disrupted contact aureole. Geologische Rundschau. 1983;72(2):637-62.

Vanorio T, De Matteis R, Zollo A, Batini F, Fiordelisi A, Ciulli B. The deep structure of the Larderello-Travale geothermal field from 3D microearthquake traveltime tomography. Geophys Res Lett. 2004;31(7):07613. doi:10.1029/2004GL019432.

Wagner W, Cooper J, Dittmann A, Kijima J, Kretzschmar H, Kruse A, Mares R, Oguchi K, Sato H, Stocker I, Sifner O, Takaishi Y, Tanishita I, Trubenbach J, Willkommen T. The IAPWS industrial formulation 1997 for the thermodynamic properties of water and steam. J Eng Gas Turbines Power Trans ASME. 2000;122(1):150-82. doi:10.1115/1.483186.

Wei ZQ, Egger P, Descoeudres F. Permeability predictions for jointed rock masses. Int J Rock Mech Min Sci Geomech Abstr. 1995;32(3):251-61. doi:10.1016/0148-9062(94)00034-Z. 